\title{
RELCA: a REgional Life Cycle inventory for Assessing bioenergy systems within a region
}

\author{
Sinéad O'Keeffe ${ }^{1 *}$, Sandra Wochele-Marx and Daniela Thrän ${ }^{1,2}$
}

\begin{abstract}
Background: The last decade has seen major development and adoption of bioenergy, particularly in Germany. This has resulted in a scattering of decentralised bioenergy plants across the landscape, due to their dependency on spatially diffuse biomass resources. Regional conditions (e.g., soils, climate, management) influence the environmental burdens resulting from biomass production and thus, also effect the environmental performance of bioenergy production. Therefore, more regionally focused life cycle approaches are required for assessing these bioenergy systems. The aim of this paper is to outline such an approach. "RELCA", is a regional life cycle inventory for assessing the regional and spatial variation in the environmental performance of bioenergy production within a region.

Methods: Five modelling steps are combined to form the RELCA approach in order to determine: (1) regional crop allocation, (2) regional biomass management, (3) representative bioenergy plant models, (4) bioenergy plant catchments, and (5) indirect upstream emissions (non-regional) associated with regional bioenergy production. The challenges and options for each of these five modelling steps are outlined. Additionally, a simple example is provided using greenhouse gases emissions (GHG) to show how RELCA can be used to identify the potential regional distribution of environmental burdens associated with the production of a bioenergy product (e.g. biodiesel) within a region.
\end{abstract}

Results: An approach for combining regionally distributed inventory for biomass production with regionally distributed inventory for bioenergy technologies, through the use of catchment delineation was developed. This enabled the introduction of greater regional details within the life cycle approach. As a first "proof of concept," GHG emissions were estimated for a simple example, illustrating how RELCA can identify the potential regional distribution of environmental burdens (direct and indirect) associated with producing a bioenergy product.

Conclusions: RELCA (v1.0) is a powerful scoping approach, which is the first to investigate the regional and spatial variation in the environmental performance of bioenergy production within a region through the use of catchment delineation. RELCA (v1.0) is not without its limitations. Despite these, it still provides a good starting point for further discussion, improvements, and modelling developments for assessing the regional and spatial environmental implications of bioenergy production (e.g., such as impacts to soil, water, and biodiversity) for a within regional context .

Keywords: Life cycle inventory, LCA, Bioenergy, Regional, Spatial assessment, GHG

\footnotetext{
* Correspondence: sinead.o-keeffe@ufz.de

'Department of Bioenergy, Helmholtz-Zentrum für Umweltforschung (UFZ)

GmbH, Permoserstraße 15, 04318 Leipzig, Germany

Full list of author information is available at the end of the article
} 


\section{Background}

\section{Assessments of bioenergy systems}

The last decade has seen major development and adoption of bioenergy in Europe, particularly in Germany [1-3]. This has resulted in a scattering of decentralised bioenergy plants across the landscape, mainly due to their dependency on spatially diffuse biomass resources. Such configurations of biomass and bioenergy technologies in the landscape make the influence of bioenergy production obvious to the eye (e.g., maize and biogas plant dominated landscapes [4]) and thus open to scrutiny for a broad list of potential environmental burdens ${ }^{1}$, to soil, to water, and land use [5-8]. In general, life cycle assessment (LCA) is the most popular assessment approach used for investigating the environmental burdens associated with bioenergy production [9-11]. However, more regionalised approaches are promoted to assess the potential environmental implications of such bioenergy configurations (i.e., bioenergy plants and their biomass catchments). Mainly, as at this scale, assessments can help to identify the distribution and range of geographical variances (e.g., climate, soil) and management practices (e.g., fertilising, tilling), which can influence the potential environmental burdens (e.g., emissions from soils) associated with biomass for bioenergy production and thus the environmental sustainability of a bioenergy product [12-14]. Such geographical and regional variances are difficult to capture using average or national values. Therefore, with regional and spatially representative life cycle assessments of bioenergy systems still evolving $[10,15-18]$, the use of three regional contexts were proposed in order to support more regional and spatial life cycle thinking ${ }^{2}$ for assessing regional bioenergy production systems [19].

\section{Regionally contextualised life cycle thinking}

LCA is essentially not designed to be a regional or spatially disaggregated approach and is considered more a global assessment tool [20]. The main reason being, that most production systems are linked to the diversity of the world's economy, making it impossible to provide a spatial orientation for the thousands of associated production activities [21]. To simplify such complexity, for life cycle assessment, all environmental burdens are aggregated across the full life cycle of a product (i.e., from the thousands of global sites with associated production activities), removing the regional or spatial patterns relating to the production and distribution of such environmental burdens [22]. However, with many environmental burdens associated with bioenergy production occurring at the regional level [13, 23, 24], there is a need to produce more regional and spatially representative life cycle assessments of bioenergy systems [10, 15, 16, 18, 25]. Therefore, the challenge is to find a balance between the increased focus on regional activities and direct environmental burdens associated with bioenergy production (e.g., emissions produced within the regional foreground) and the requirement to account for the nonregional environmental burdens also associated with such regional bioenergy production (i.e., emissions produced upstream, not within the regional foreground, but elsewhere outside the region). In this way, the burdens related to production activities for the full life cycle of a bioenergy product can be taken into account.

O'Keeffe et al. [19] in their review of the literature identified regional and non-regional environmental burdens associated with bioenergy production. Considering these burdens, they aimed to determine how much of a regional focus could make sense for assessing the environmental performance of a particular bioenergy system, while maintaining the major concepts of life cycle thinking. Defining the regional scope as one scale lower than a country $[12]^{3}$ and a bioenergy production system as the combination of different feedstocks and technologies used to produce a particular bioenergy product (Fig. 1), they identified three regional contexts which have been used to frame regionally focused life cycle thinking. With many burdens of bioenergy production strongly influenced by the regional variability (e.g., management, climate, soil) of biomass production $[5,6,23$, 24, 26-28], O'Keeffe et al. [19] identified the need to begin determining what is happening "within" a regional context for a bioenergy producing region. They also identified that life cycle thinking framed in a regionally contextualised manner is at a nascent stage, particularly with regard to implementing a suitable or appropriate life cycle impact assessment phase ${ }^{4}$. For this reason it was suggested, as a first step, to begin exploring regionally contextualised life cycle thinking with the development of life cycle inventory assessments.

\section{Aim of paper}

Therefore, the aim of this paper is to outline the steps, along with their challenges and options, for developing one of the regional contexts outlined by O'Keeffe et al. [19] into a practical life cycle approach. "RELCA" is a regional life cycle inventory for assessing the environmental burdens of producing a bioenergy product "within" a regional context. The objective of RELCA is to establish a regionally distributed life cycle inventory, which combines both regional bioenergy technologies with their associated biomass feedstocks for an entire region. This enables the use of bioenergy configurations (e.g., bioenergy technologies and biomass) to explore the regional variability of direct regional environmental burdens 


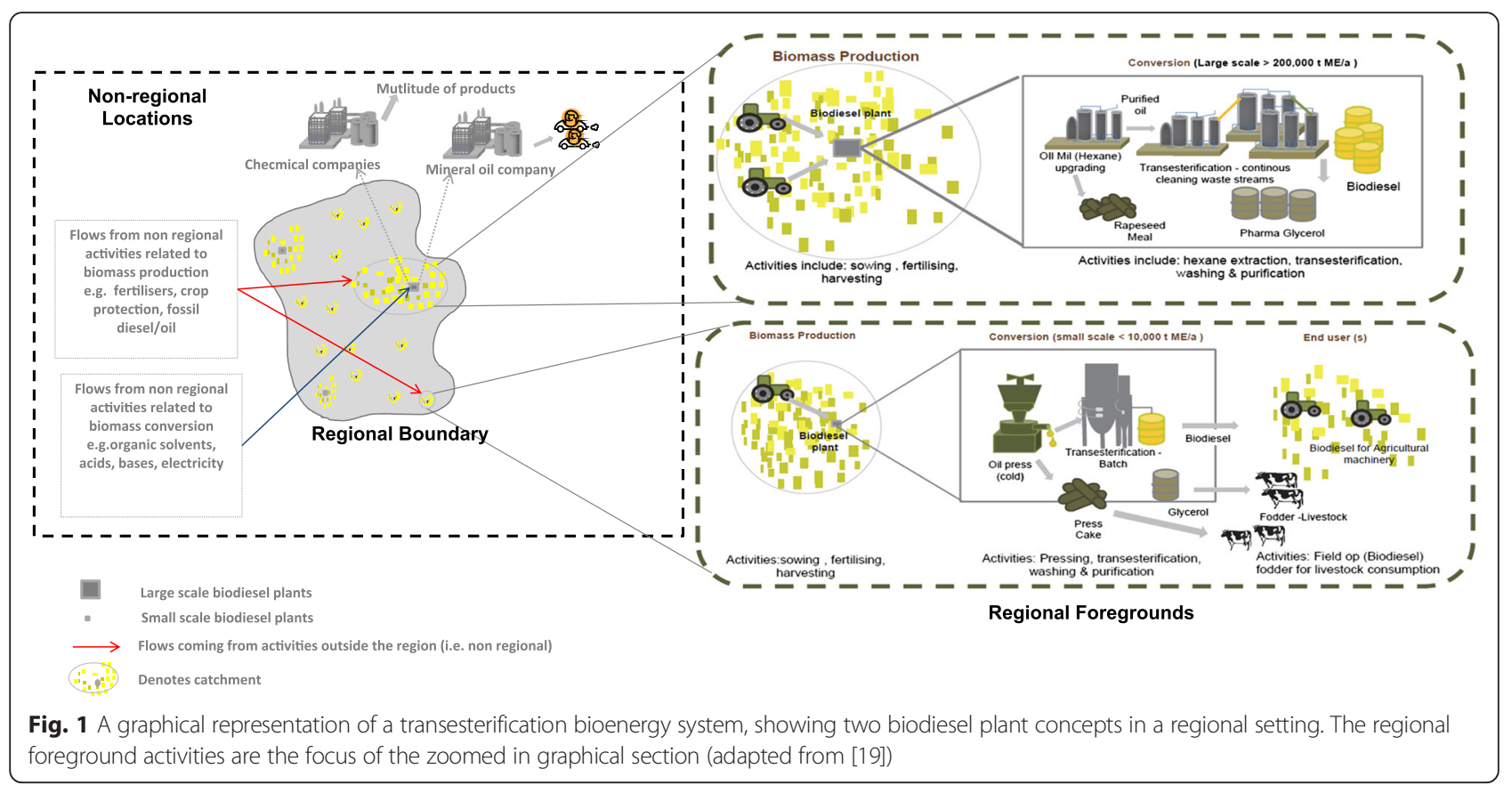

(i.e., those occurring within the regional foreground), as well as the indirect non-regional burdens (i.e., those occurring outside the region of focus) associated with the production of a regional bioenergy product (e.g., biodiesel, bioethanol, biogas), thus helping to determine the environmental performance of a regional bioenergy product.

As a first step, a brief outline of the RELCA approach is provided. Key issues and aspects relating to the five major steps involved in developing RELCA (Fig. 2) are then outlined. Additionally, a simple illustrative example, using greenhouse gas emissions (GHG) is provided, to show how RELCA can be used to identify the potential distribution of environmental emissions associated with the regional production of a bioenergy product, such as biodiesel. To note, if the concepts of regionally contextualised life cycle approaches for assessing bioenergy systems are not familiar to the reader, it is recommended to read the review of $\mathrm{O}^{\prime}$ Keeffe et al. [19] for a more in-depth understanding of the underlying theoretical concepts for this approach.

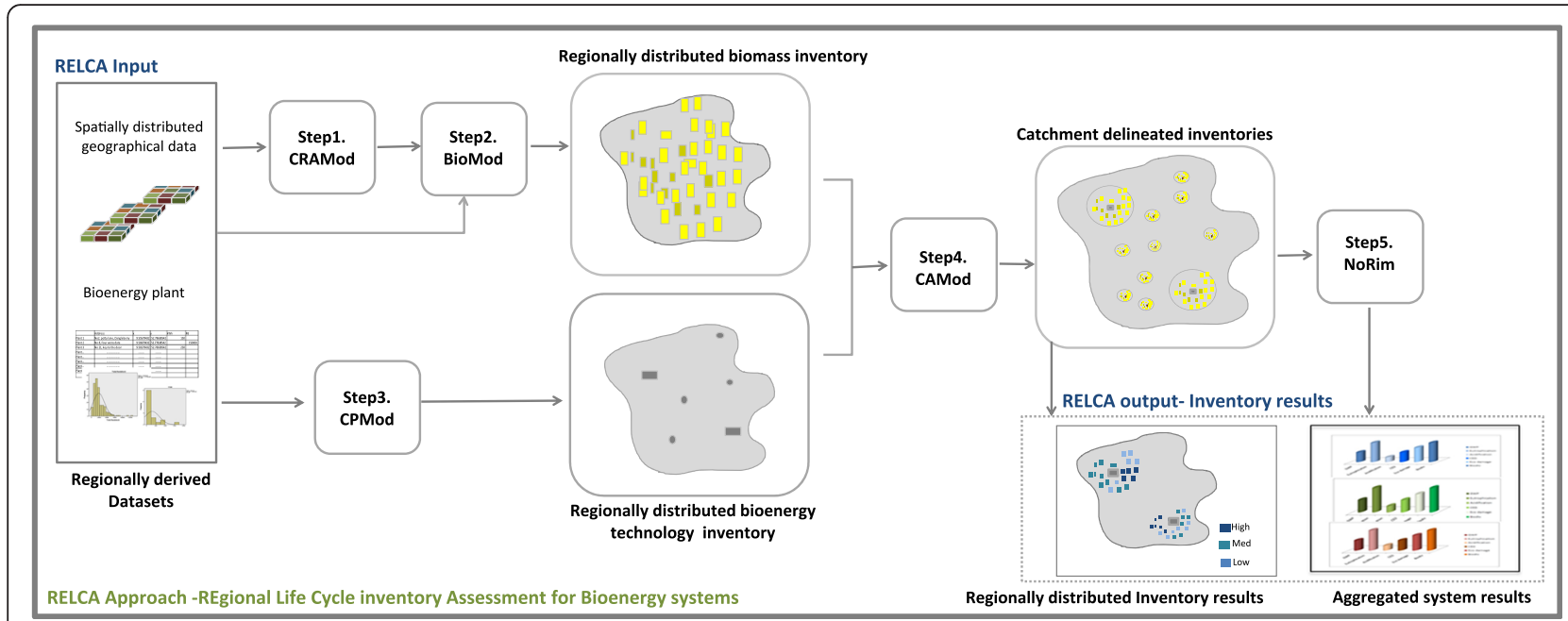

Fig. 2 Outlines the RELCA approach and the various integrated modelling steps. (1) CRAMod-crop allocation modelling. (2) BioMod-biomass inventory modelling. (3) CPMod-conversion plant modelling. (4) CAMod-catchment allocation modelling. (5) NoRiMod-non regional inventory modelling 


\section{Methods}

\section{What is RELCA?}

RELCA is a life cycle inventory (LCI) assessment approach which can be used to assess the environmental performance of bioenergy produced "within a regional context" [19] (Figs. 1 and 2). It is a retrospective scoping approach, applicable to projects which aim to either "monitor" the status quo of a region's existing bioenergy production (e.g., retrospective, attributional LCI [29]), or which aim to explore different options for improving the burdens relating to the existing regional bioenergy production "micro change" (e.g., system expansion through substitution [29]). Goal depending, two major functional units can be used in this approach, either emissions per function of energy produced (MJ), or emissions per function of land used (ha) [30]. It can be used to answer more spatially orientated questions such as: how much of an environmental burden is coming from within my region of activity (e.g., due to cultivating biomass), how much is non-regional? Where are the burdens of my regional activities being produced? Are there regional hotspots (i.e., areas within my region which indicate a higher potential for emissions)?

RELCA consists of three major steps to produce two regionally distributed inventories (Fig. 2). Two steps are required for producing the regionally distributed biomass inventory, with one step required for establishing the regionally distributed bioenergy technologies inventory. In a succeeding step, catchment delineation is used to integrate both regionally distributed inventories to form inventories for each individual bioenergy configuration (e.g., bioenergy plant and supplying biomass). In a final step, these catchment delineated inventories are linked to the associated non-regional inventory (Fig. 2). The main modelling steps involved are as follows:

1. Crop Allocation Modelling (CRAMod) to generate the potential biomass availability or regional distribution of energy crops which can theoretically be used by regional bioenergy systems.

2. Biomass inventory Modelling (BioMod) to develop the mass and energy balances (inputs and emissions) relating to the cultivation of the associated energy crops used in the bioenergy system of interest.

3. Conversion Plant Modelling (CPMod) to develop representative bioenergy plant models (process based) for the bioenergy conversion systems in the region, along with determining their spatial distributions.

4. Catchment Modelling (CAMod) to assign the regionally distributed bioenergy crops to the various bioenergy conversion plants across the region.

\section{Non-Regional Inventory Modelling (NoRIMod) to identify and link the indirect upstream emissions, to the direct emissions produced within the region. Upstream emissions are assumed to be produced externally to the region.}

There are no hard or fast rules for which modelling tools should be implemented for each of the associated steps, as this depends on the goal of a particular study or the skill sets of a particular research group. However, to be considered a RELCA approach, all five steps need to be carried out in the manner outlined in Fig. 2. As RELCA consists of a regionally distributed foreground inventory, geographic information system (GIS) software is a key support tool for modelling and spatialisation of the inventory data. This can then be used in combination ${ }^{5}$ with python or other programming and scripting tools (e.g., $\mathrm{C}++$, MATLAB, or $\mathrm{R})^{6}$, as well as Microsoft Excel to model and compute the necessary flows (mass, energy, emissions) outlined in the different steps of RELCA. The use of life cycle software is also a key tool for supporting the life cycle inventory structure and for connecting the non-regional flows (e.g., upstream unit processes from Ecoinvent) with the regional foreground flows (derived for the particular study). In the following sections we discuss the challenges and options for the different steps involved in the RELCA approach (Fig. 2).

\section{Step 1. CRAMod step-crop allocation modelling}

The lack of more exact spatially differentiated data (e.g., what is grown where) for energy crop production, (e.g., due to confidentiality issues ), is a known bottleneck in making more spatially detailed assessments of biomass-tobioenergy pathways [31, 32]. Therefore, alternative approaches have been developed to deal with the issue of crop allocation [33]; here, we refer to them as CRAMod approaches. Many approaches used for spatially allocating crops are based on principles of economic optimization (e.g., farmers or plant owner's profitability) such as; agent based modelling [34], linear optimization modelling [35, 36], or Marchov chain modelling [37]. However, other non-economic approaches for spatially allocating crops also exist. These use a combination of geographical constraints such as crop growing preferences (e.g., soil type, climate), detailed regional land use, and cropping statistics [31]. The latter might be more preferable where economic outcomes are not part of the study's focus.

For many European based studies investigating the spatial aspects of biomass production, the Corine land cover dataset (CLC) [38] is used as a base layer to identify the distribution of arable land used within a particular region [39]. This is then overlaid with other geo datasets containing information on various environmental properties (e.g., soil type, annual rainfall, temperature) [31, 39]. In many cases 
for such spatial modelling, geographical data is divided into "land parcels" or grids cells, as this enables a particular process to be modelled for each of the constituent grid cells [40-42]. These grid cells, attributed with all the relevant information (e.g., crop, yields, soil type and climate) are then used as the input for the CRAMod approaches outlined above.

The structure and aggregation of geo data into these "grid cells" is, however, a key consideration for any regionally distributed biomass inventory. Therefore, at the beginning of the study deciding on the most appropriate unit(s) of aggregation ensures that the regional inventory flows include the relevant geographical characteristics to (1) enable the estimation of potential regional crop distributions [31], (2) account for the desired regional and spatial variances, which influence the potential emissions of interest in relation to biomass production [43, 44], and (3) helps reduce aspects of MAUP (modifiable areal unit problem) an unavoidable issue in geographical studies ${ }^{7}$.

The output from the CRAMod step is the cornerstone of the RELCA approach. It is a geodataset comprising of constituent regional grid cells, with each grid cell containing important regional geographical variables (e.g., climate, soil types, agricultural suitability), as well as the energy crop allocated to a particular grid cell by the crop allocation model implemented. Thus, this provides the regional biomass availability required for the CAMod step. It also contains the geographical variables to model management and emissions, for the associated energy crop cultivation which should be used in the next step, BioMod.

\section{Step 2. Biomod-biomass inventory modelling}

The magnitude of emissions from energy crop production depends on the production locations within a region and therefore, the associated regional variations in turn can have a significant influence on the environmental performance of the associated bioenergy systems [28, 45-47]. For this reason the purpose of the BioMod step is to determine the regional management practices, as well as the direct emissions associated with producing energy crops within a region. These management flows and emissions are calculated for each of the regional grid cells assigned to the particular energy crop, determined in the previous step. The calculations for the BioMod step can be performed using either a python based scripting tool in Esri $\mathrm{ArcGIS}^{\circ}$ or through other programming languages such as $\mathrm{C}++$ or MATLAB ${ }^{6}$ (see Additional file $1, \mathrm{~S} 1$ for an example).

For ease of discussion and because of its relevance for bioenergy production, we focus the discussion here on one category of emissions-greenhouse gases (GHG). In order to determine GHGs associated with biomass production, we need to first determine the potential biomass management practices implemented within the region. Modelling exact management practices of different farmers across a region is near impossible, unless such empirical data is available (e.g., farm survey data) [48]. However, an alternative approach to bridge this data gap is to use recommended best energy crop management practices and available information provided by regional agricultural institutes or advisories as proxies [39, 49]. The application of nitrogen fertiliser is an important example of such management practices, as this has been identified as contributing significantly to the GHG balance of energy crop production $[45,50,51]$. We therefore, use nitrogen management as an example to show how the BioMod step is carried out (Fig. 3, see also Additional file 1, S2 for a more detailed explanation of the calculations).

The management flows are split in two (Fig. 3): the foreground input flows, which are the main nutrient flows $\left(\mathrm{AppF}_{\mathrm{m}}\right)$ in the regional foreground (e.g., nitrogen) and the background non-regional input product flows $\left(\mathrm{FP}_{\mathrm{i}}\right)$, which are supplying the nutrients (e.g., the fertiliser product calcium ammonium nitrogen (CAN)). In the end, as shown in Fig. 3, each grid cell will be attributed with the direct regional foreground flows (e.g., $50 \mathrm{~kg}$ of nitrogen), as well as the total induced demand for non-regional products supplying the foreground flows (e.g., $185 \mathrm{~kg}$ of CAN). Similarly the steps employed for estimating the fertiliser management practices can also be applied to estimate other cultivation practices such as, crop protection (e.g., regional flows $=$ active ingredients ${ }^{8} /$ non-regional flows $=$ pesti cide products). Additionally, the diesel consumption and emissions associated with mechanical field operations (e.g., ploughing, harvesting) can be modelled for each grid cell. This is done using the potential tractability of the attributed soil properties, e.g., heavy or light soil (usually based on $\%$ clay) $[48,52]$.

After the regional management input flows have been determined, the next step is to estimate the associated direct regional GHG emissions induced as a result of such management practices, e.g., $\mathrm{kg} \mathrm{N}_{2} \mathrm{O}$ released per $\mathrm{kg}$ nitrogen fertiliser applied. The IPCC provides three Tiers of accounting [53]. For the regionally distributed approach, Tier 2 is the basic calculation which should be used to estimate the potential greenhouse gas balances, as this includes basic geographical considerations (e.g., yields, climate). However, the more idealised means of life cycle accounting is the inclusion of results (Tier 3 ) from more complex process based models (e.g., DNDC [54-56], DAYCENT [50]), which can be used to estimate GHG emissions. Indeed the integrated use of GIS and biogeochemical models is increasingly being employed to estimate regional distributions of greenhouse gas (GHG) emissions [57-60]. 


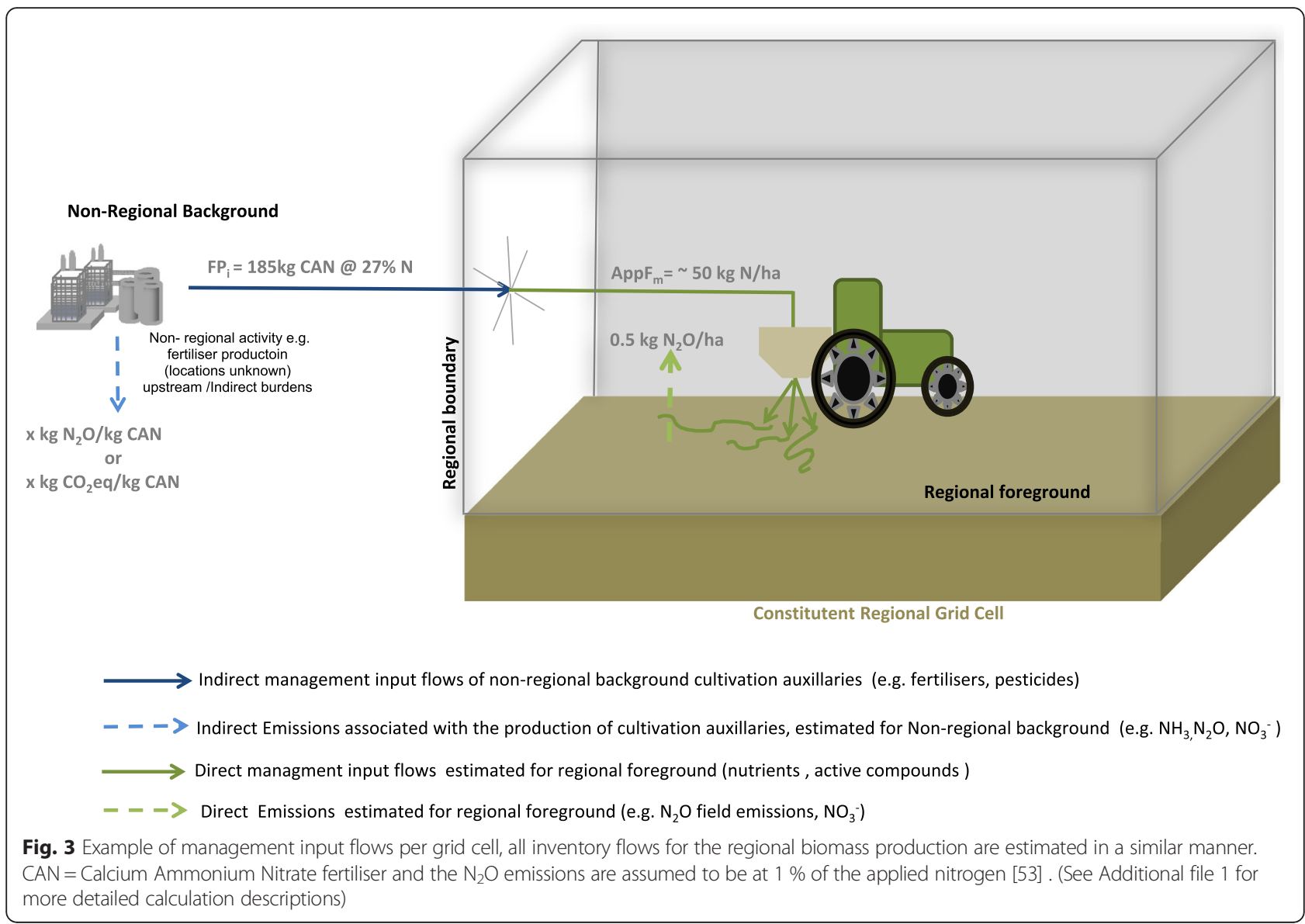

The combined output of the CRAMod Step and the BioMod step produces the regionally distributed biomass inventory (Fig. 2). This is a geodataset which contains, for each grid cell, the direct foreground flows (e.g., nutrients, active ingredients, emissions from soils, exhaust emissions from farm equipment) relating to activities of biomass production within the region. It also contains, for each grid cell, the demands for the non-regional product flows, as shown in Fig. 3 (e.g., fertiliser products, crop protection product, diesel demand).

\section{Step 3. CPMods-conversion plant models}

The purpose of the CPMod step is to determine representative bioenergy plants or model plants for the bioenergy system or systems of interest. We refer to regional bioenergy systems (e.g., transesterification), as the total combination of different regional bioenergy chains producing the same energy product (e.g., biodiesel), but which may comprise of different feedstock/technology combinations and hence different regional configurations [19]. A bottom up process-based approach is taken to develop the mass and energy balances for each representative model plant. Additionally, the CPMod step determines the spatial locations and distribution of the different bioenergy plants associated with a bioenergy system, within a particular region (i.e., a point shapefile).
To date (at time of writing), there is little or no available literature on how to develop inventories for existing bioenergy technologies within a region (i.e., process based mass and energy balances), as it is not something commonly done. This is mainly due to lack of data, it is too time intensive, or the development of bioenergy has not been so extensive. However, one approach has been outlined and we use this as a guideline for the discussion here [15]. The purpose of the bioenergy plant inventory is to develop conversion plant models (CPMods) for a conversion system (e.g., anaerobic digestion-model biogas plants, transesterification-model biodiesel plants), which are representative of the regional situation (Fig. 1). The development of the representative conversion plant models can be carried out through a combination of Microsoft Excel ${ }^{\circ}$, Aspen Plus ${ }^{\circ}$ and life cycle software (e.g., GaBi, SimaPro, Open LCA) ${ }^{6}$. However, the challenges for developing representative regional model concepts are different for each conversion system and therefore, need to be approached and handled differently.

For large "non-diffuse" bioenergy conversion systems (e.g., fermentation-consisting of a few large-scale bioethanol plants), direct partnership with the plant operators is the ideal means for developing these specific conversion plant inventories (process-based mass and energy balances) [61]. Unfortunately, this is not always possible (e.g., confidentially issues, time constraints), therefore, an alternative 
option is to try and obtain information from annual reports and regulatory environmental documents, which they are legally obliged to publish each year. A combination of literature values and expert opinion, as is what is traditionally done to complete the life cycle inventory, could then be used. However, as the conversion plant models are required to be representative of a region, the limitation of its regional representativeness should also be acknowledged in the interpretation of the results $[62,63]$.

For spatially diffuse bioenergy systems (e.g., anaerobic digestion - consisting of many biogas plants scattered across the region), it is not always easy to obtain detailed information for each individual plant, or process steps, due to the sheer number of bioenergy plants and the potentially vast number of feedstock and technology combinations (e.g., as observed in anaerobic digestion and combustion systems). Therefore, bioenergy plant clusters can be developed [64]. There are a number of options for inventory collection, such as: surveys, on-line databases $[65,66]$, or data provided by grid operators (e.g., $50 \mathrm{Hertz}$ in Germany) [2,3]. In the ideal case where sufficient data has been collected, various different statistical techniques can be employed for data mining e.g. summary statistics, correlations, distribution analysis (both spatial and nonspatial) $[15,67]$. This helps to identify key parameters for clustering the conversion technologies (e.g., feedstocks, installed capacities etc.). These clusters can then be used to develop the process based conversion plant models which are representative of regional conditions [15].

The spatialisation of bioenergy plant data is an additional challenge for the bioenergy technology inventory. For nondiffuse bioenergy plants, determining spatial locations should be relatively straightforward processes (e.g., low numbers present, large and easily seen in Google maps), whereas the spatial distributions (point locations) of spatially diffused conversion systems are a little more challenging. In many cases, addresses for the individual bioenergy plants are provided in tabular format $[65,66]$, which require further processing for use in spatial analysis software (e.g., GIS). Options can range (depending on number of bioenergy plants) from manual $(x, y)$ coordinate conversion in Google maps, to using a combination of Google Fusion and Google Earth to geocode and convert to a GIS compatible file format, such as keyhole mark-up language (KLM) [68]. For larger data sets using more complex spatialisation approaches, it is also suggested to conduct a visual assessment with Google maps using a representative sample number of bioenergy plants in order to determine the potential level of uncertainty associated with such point data. Additionally, the final locations of these bioenergy plants should also be crossed reference with another data set if available [69].

The output from the CPMod step is the regionally distributed bioenergy technology inventory. In other words this is a geodataset (i.e., point shape file) containing information on the locations, installed capacities, production capacities, as well as the categories of conversion plant models assigned to each bioenergy plant. Additionally, it should also contain the distributed demand functions for each bioenergy plant, which is an important parameter to be used in the CAMod step. Furthermore, for each of these conversion plant models, process models should be developed concurrently in the life cycle software of choice (e.g., GaBi, SimaPro, Open LCA) ${ }^{7}$.

\section{Step 4. CAMod-catchment allocation modelling}

The purpose of the CAMod step is to combine the regionally distributed bioenergy technology inventory with the regionally distributed biomass inventory as in Fig. 2. This is done by assigning the biomass to the associated conversion plants using the demand function determined in the CPMod step (i.e., tonnes of bioenergy crop required for their annual production capacities). In this way the spatial configuration of the bioenergy plants' catchment areas, or area required to supply biomass to the conversion plants are estimated. Many factors influence the size of the catchment area such as yields, biomass availability, economics, operational capacity of the bioenergy plants, and its efficiency.

With the application of GIS software (e.g., Esri ArcGIS ${ }^{\circ}$ buffer tool), many assessments use a circular based configuration for the catchment area of a bioenergy plant, with the radius of the circle used to estimate the transport distance to the plant [70-72]. The calculation of this radial transport distance can be based on simple demand-supply properties (i.e., $x$ tonnes of biomass required and it takes y number of hectares with a yield $\mathrm{z}$ ), or more advanced calculations using the approach of [73]. The latter includes aspects of biomass availability and tortuosity (e.g., windiness factor of the landscape/roadways). Additionally, more complex cost supply curves can also be implemented, which use a combination of geographical and economic variables to determine the potential distances travelled for harvesting the biomass (e.g., using various cost accounting methods) [74-76]. Which approach is implemented depends on the goal of the particular study. However, most approaches can only process the calculation of one catchment at a time, or several catchments if they are assumed to have the same capacity. Therefore, with bioenergy plants of various different capacities installed in a region, a more flexible approach is required to estimate all the potential catchments simultaneously, such as [77], who used a programming approach (FORTRAN) to model the heterogeneous bioenergy plant catchments.

The output of the CAMod step is catchment delineated inventories, for each bioenergy configuration (e.g., bioenergy plant and associated biomass), associated with the bioenergy system(s) of interest. In other words, both biomass and bioenergy plant inventories are now combined for each bioenergy configuration as a result of the CAMod step (Fig. 2). Delineating the inventory for each bioenergy configuration is one of the most important calculations in the RELCA framework, as the catchment area sets the boundary for aggregating all the relevant foreground flows (e.g., mass, energy and emissions) $[75,78,79]$. It is also the most basic indicator of land use (land occupation) within the region [25]. 
Step 5. NoRIMod-non-regional inventory modelling

The purpose of the NoRiMod step in the inventory accounting is to link the indirect upstream emissions generated outside the region, to the direct emissions produced within the regional boundary. The regional boundary denotes the foreground activities relating to the bioenergy systems being assessed [12, 29, 80, 81]. However, such foreground activities also require inputs from outside the region (e.g., fertiliser products, fossil fuels, grid energy), these can be considered as flows from the "non-regional background" (Figs. 1 and 3). This means, that the activities involved in producing these products (or flows), as well as their associated burdens, are released everywhere else but in the region of focus, i.e., they are non-regional burdens.

As the focus of RELCA is "within the regional" boundary, the spatial locations of where potential burdens occur within the region are of interest. Therefore, the direct regional burdens are estimated for each constituent regional grid cell, thereby producing a regional distribution of direct burdens (see Table 1) associated with the regional foreground activities of bioenergy production. For the RELCA approach the spatial locations for the indirect non-regional burdens (i.e., where in the world they are produced) are not of interest and they can be summated to a single aggregated value (see Additional file 1, S.3).

For biomass production the bulk of the non-regional burdens come from the production of fertiliser products, crop protection products (e.g., pesticides, insecticides) and fossil diesel (Table 1). For many bioenergy plants the majority of non-regional burdens come from production of auxiliaries and upstream energy supply. Indeed for the bioenergy conversion step the majority of associated emissions are more than likely to occur outside of the region [82-84], of course this depends on regional plant designs. However, for some bioenergy conversion technologies, such as combustion, it may be necessary to have foreground modelling of the conversion step, as direct emissions from chimney stacks may be of key regional concern [85-87]. In this case, such considerations should be made during the CPMod step.

For the simplest NoRIMod ${ }^{9}$ accounting, the mean mass and energy flows for the total biomass supplied to a bioenergy plant (i.e., the bioenergy plant catchment), can be used as input for the designated life cycle software (e.g., GaBi, SimaPro, Open LCA) ${ }^{6}$, similar to conventional life cycle approaches (i.e., taking the mean). Once all the mean foreground flows (e.g., $\mathrm{kg}$ of nutrients) have been estimated and the associated upstream products (e.g., kg of fertiliser products) have been determined, as shown with the nitrogen fertiliser example in Fig. 3, the connections between the regional foreground and background flows can be made with the help of the life cycle software (i.e., using process units for each of the different biomass producing activities). Again similar to how conventional life cycle is conducted, the mass, energy and emission flows associated with the biomass production of a particular bioenergy plant catchment are then linked, within the life cycle software, to the bioenergy conversion plant models, which have already been established as part of the CPMod step.

The output of this step is a connected life cycle inventory which differentiates between within regional environmental burdens and non-regional environmental burdens (see Additional file 1).

\section{Regional life cycle inventory assessment (RELCA)}

Continuing with the example of GHG emissions, once the NoRIMod step is completed, a life cycle inventory assessment for the related GHG burdens ${ }^{10}$ can be carried out for each bioenergy configuration within the region (see Additional file 1, S.3: for a fuller description). Carrying out a life cycle inventory assessment for each bioenergy configuration can be a viable option for non-diffuse bioenergy plants (i.e., low number of bioenergy plants within the region). However, for conversion systems which are more spatially diffuse (e.g., biogas) and have a greater number of bioenergy plants scattered across the region, it would be time intensive to calculate an inventory assessment for each of these bioenergy configuration. For this reason, the aggregation of individual bioenergy configurations to their assigned bioenergy clusters, determined during the CPMod step, may be a preferable means to handle such information. In this way the regional ranges for the cluster, i.e., the min, max and mean mass and energy flows are determined. These values can then be inputted into the life cycle software to provide an LCI for the range of potential emissions (e.g., min, mean, max) associated with a bioenergy cluster, which could consist of hundreds of bioenergy plants [14]. Additionally, RELCA can also be used to estimate both the direct and induced indirect input flows and emissions estimated per functional unit of energy or per hectare supplied for the constituent grid cells of a region (see Additional file 1, S.3 for a more detailed explanation).

\section{Outputs of RELCA-inventory results}

There are two output inventory results from the RELCA approach, the regionally distributed and the non-regionally aggregated (Fig. 2). Both outputs should be used together to identify the potential regional environmental burdens of producing a bioenergy product. The regionally distributed inventory results in the GIS software can help to identify where potential burdens are occurring at higher or lower intensities, i.e. potential geographical "hotspots" for bioenergy production. This also enables the exploration of potential underlying geographic influences on the associated life cycle balances. The aggregated inventory result from the life cycle software provides an indication of the overall performance of the regional bioenergy production, identifying the activities within and outside the region that induced the overall greatest environmental burdens. 


\section{Application to a simple illustrative example}

To show how RELCA can be implemented, we present a simple illustrative example, based on the regional data of two East German federal states (Saxony and Thüringen). While aspects of the example pertain to the geographical characteristics of the actual region, we have modified certain details (e.g., bioenergy plant numbers) in order to provide a simple illustrative example of how the RELCA approach can be employed. The goal of the simple example is to use RELCA to determine for one operational base year: (1) the potential regional distribution of direct GHG burdens (emissions) associated with the production of $1 \mathrm{MJ}$ of biodiesel, which is also the functional unit and (2) to determine the percentage direct emissions and indirect emissions for the overall regional biodiesel production. The RELCA approach applied was retrospective and complied with the ISO LCA standards [88]. An attributional life cycle accounting approach was implemented $[19,29]$ and for simplification, all GHGs emissions were allocated based on energetic content.

\section{Step 1. CRAMod for rapeseed availability inventory}

In order to determine the distribution of arable land for the study region the Corine land cover (CLC) [38] was used and organised into land use parcels or grid cells of
25 hectares $\left(500 \times 500 \mathrm{~m}^{2}\right)$ using the Fishnet function of ESRI ArcGIS 10.1. This gridded land use layer was then overlaid with different geographical data for the region (e.g., soil types and climate). The crop allocation model of Wochele et al. [29]was implemented, which used the geographical attributes of the gridded land use layer (soil type [89], Ackerzahl value ${ }^{11}$ [90]) in combination with regional cropping statistics for the year 2010 [91], in order to produce a regionally distributed energy crop layer. From this the regional biomass availability of rapeseed with yields ranging from 2.31 to $4.41 \mathrm{tha}^{-1}$ (fresh matter) was determined for the example study region.

\section{Step 2. BioMod-biomass inventory modelling}

The key direct emissions associated with biomass production are outlined in Table 1, with the relevant inventory assumptions also provided (see also Additional file 1, S.4). It was assumed that farmers in the region used "best farming practices" for rapeseed production [92]. All direct regional management practices and associated emissions were allocated and estimated for each rapeseed grid cell using MATLAB 2012 $\mathrm{b}^{6}$ based scripts (see Additional file 1, S.1 for BioMod step). The resulting output is the GHG emissions associated with producing one hectare of rapeseed.

Table 1 Examples of environmental regional and non-regional GHG emissions for the example case study's transesterification bioenergy system (excluding aspects relating to infrastructure). All regional burdens (GHG emissions) were calculated for each constituent regional grid cell. Non-regional burdens were calculated in an aggregated manner, i.e., no spatial resolution taken into account

\begin{tabular}{|c|c|c|c|}
\hline Regional activities $^{\text {a }}$ & Regional burdens ${ }^{b}$ & Non-regional burdens ${ }^{c}$ & Non-regional activities \\
\hline \multicolumn{4}{|l|}{ Biomass production } \\
\hline Field operations $^{d}$ & Exhaust emissions $\left(\mathrm{CO}_{2}, \mathrm{~N}_{2} \mathrm{O}, \mathrm{CH}_{4}\right)$ & $\mathrm{CO}_{2}, \mathrm{~N}_{2} \mathrm{O}, \mathrm{CH}_{4}, \mathrm{SF}_{6}, \mathrm{NMVOCs}$ & e.g., oil extraction, refining to diesel \\
\hline Application of fertiliser ${ }^{\mathrm{e}}$ & Field emissions $\mathrm{N}_{2} \mathrm{O}^{\mathrm{f}}, \mathrm{NH}_{3}$ & $\mathrm{CO}_{2}, \mathrm{~N}_{2} \mathrm{O}, \mathrm{CH}_{4}, \mathrm{SF}_{6}, \mathrm{NMVOCs}$ & e.g., production of various fertilisers ${ }^{9}$ \\
\hline $\begin{array}{l}\text { Application of other } \\
\text { management products }^{\text {h }}\end{array}$ & No direct GHG emissions & $\mathrm{CO}_{2}, \mathrm{~N}_{2} \mathrm{O}, \mathrm{CH}_{4}, \mathrm{SF}_{6}, \mathrm{NMVOCs}$ & $\begin{array}{l}\text { e.g., production of management } \\
\text { products }\end{array}$ \\
\hline Land used & n.a. & n.a. & n.a. \\
\hline \multicolumn{4}{|l|}{ Transport } \\
\hline Transport to biodiesel plant ${ }^{j}$ & Exhaust emissions $\left(\mathrm{CO}_{2}, \mathrm{~N}_{2} \mathrm{O}, \mathrm{CH}_{4}, \mathrm{R} 134\right)$ & $\mathrm{CO}_{2}, \mathrm{~N}_{2} \mathrm{O}, \mathrm{CH}_{4}, \mathrm{SF}_{6}, \mathrm{NMVOCs}$ & e.g., oil extraction, refining to diesel \\
\hline \multicolumn{4}{|l|}{ Conversion } \\
\hline Oil mill extraction ${ }^{k}$ & No direct GHG emissions & $\mathrm{CO}_{2}, \mathrm{~N}_{2} \mathrm{O}, \mathrm{CH}_{4}, \mathrm{SF}_{6}, \mathrm{NMVOCs}$ & $\begin{array}{l}\text { e.g., electrical energy (national grid), } \\
\text { natural gas (national characteristics) } \\
\text { auxiliaries }{ }^{1} \text {, e.g., acids, hydroxides }\end{array}$ \\
\hline Transesterification and purification & - & $\mathrm{CO}_{2}, \mathrm{~N}_{2} \mathrm{O}, \mathrm{CH}_{4}, \mathrm{SF}_{6}, \mathrm{NMVOCs}$ & (same as oil mill) \\
\hline
\end{tabular}

${ }^{\mathrm{a}}$ Regional activities refer to activities of bioenergy production within the region

${ }^{\mathrm{b}}$ Regional burdens-main environmental interventions, i.e. resource uses and emissions induced in the region

${ }^{c}$ Non-regional burdens refer to all burdens produced outside the region, from non-regional activities outside the region (not complete list)

${ }^{d}$ Field operations refer to machine operations [93]. Provides fuel consumption estimates for three different soil types, assumed to be similar to those outlined by [94]; light ( $<12 \%$ clay), medium (13-25\% clay) and heavy ( $>25 \%$ clay)

${ }^{e}$ Rates of nitrogen fertiliser assumed ranged from 134-179 $\mathrm{kg} \mathrm{N} \mathrm{ha}^{-1} \mathrm{a}^{-1}$ and were determined based on the yield statistics for East Germany (See Additional file 1) fDirect emissions of nitrous oxide $\left(\mathrm{N}_{2} \mathrm{O}\right)$ were estimated according to the German national guidelines [95] using a Tier 2 approach [96], with the emission factors based on geographical parameters outlined by [97] used and using climate data (daily precipitation and temperature)— provided by the German weather service ${ }^{9}$ Fertiliser mixes for the region were determined from regional sales statistics [98] (See Additional file 1)

hOther management products such as pesticides, herbicides etc. (See Additional file 1)

'Relating to shifts in soil organic carbon, for simplicity no land transformations were assumed to occur within the region. Additionally, for ease of calculation here and because it is a simplistic example we do not include $\mathrm{CO}_{2}$ emissions in relation to changes in soil carbon due to the cropping system

'The emissions outlined in Eco Invent 2.2 (CH: operation, lorry 20-28 t, full, fleet average [Street] [99] ) were used and only one journey to the plant was taken into accounted

ksee Table 2

'See Table 2 


\section{Step 3. CPMod inventory}

The operational base year selected was estimated from the point of harvest in autumn, through to the autumn of the following year. For this simple example five biodiesel plants were assumed to be operating in the region, with rapeseed as the main oilseed feedstock. Installed capacities ranged from 2000-55,000 tonnes of biodiesel per year. Those plants with installed capacities of less than 10,000 tonnes of biodiesel per year were classified as small scale, with plants above this assumed to be medium scaled (Table 2). For the operating base year, the annual production capacities were also assumed to be $52 \%$ of installed capacity [3]. The mass and energy balances, for the model plant concepts are outlined in Table 2, as well as important modelling considerations for the modelling step. Additionally, the associated GHG emissions are also outlined in Table 1. The rapeseed demand vector for each model biodiesel plant was determined by (1) their installed capacities, (2) the assumed operational capacities (i.e., $52 \%$ [3]), and (3) the estimated conversion efficiency from rapeseed to biodiesel. Additionally, the locations for each biodiesel plant within the region were determined and the coordinates generated using Google maps.

\section{Step 4. CAMod}

Using MATLAB2012b ${ }^{6}$ generated scripts, the Euclidian distance $r_{j}$ was estimated for all biodiesel plants $\left(x_{n}, y_{n}\right)$ to every rapeseed pixel $\left(x_{\mathrm{i}}, y_{\mathrm{i}}\right)$ (Eq. 1). Distances for each rapeseed grid cell to a biodiesel plant $\left(r_{\mathrm{j}}\right)$ were then sorted for each plant according to increasing distance from the particular biodiesel plant. Each grid cell had also an associated yield

$$
r_{j}=\sqrt{\left(X_{n}-X_{i}\right)^{2}+\left(Y_{n}-Y_{i}\right)^{2}} .
$$

It was assumed that the smaller biodiesel plants are more likely is to use rapeseed sourced from the region, therefore the model runs start with the smaller biodiesel plants first. The catchments grew in size, (i.e., the consecutive yields were added) until the demand for rapeseed (i.e., tonnes required per annum) of all the biodiesel plants were satisfied in one simulation run. Additionally, if a rapeseed grid cell was closer to one biodiesel plant than another, the rapeseed grid cell was allocated to the closest biodiesel plant to avoid catchment area overlap (i.e., things closer are more likely to be related [103]). The particular catchment for each biodiesel plant was then used to estimate the associated life cycle inventory (fieldto-gate). In order to keep the simulations simple, it
Table 2 Activity parameters for conversion plants in the regional foreground. Model plant concepts representative of the region were developed in collaboration with the German Biomass Research Centre (DBFZ) [64]. All flows unless otherwise stated are $\mathrm{kg} / \mathrm{MJ}$ biodiesel produced, values have been rounded up to the nearest decimal place

\begin{tabular}{|c|c|c|}
\hline & Small & Medium \\
\hline \multicolumn{3}{|l|}{ Infrastructure } \\
\hline Oil mill & Cold press & Hot press \\
\hline Biodiesel plant & Batch & Continuous \\
\hline \multicolumn{3}{|l|}{ Oil mills } \\
\hline Rapeseed & $7.98 \times 10^{-1}$ & $6.72 \times 10^{-1}$ \\
\hline Electricity input $\left(\mathrm{MJ} \mathrm{MJ}^{-1}\right)^{\mathrm{a}}$ & $2.69 \times 10^{-1}$ & $2.3 \times 10^{-2}$ \\
\hline Thermal energy input $\left(\mathrm{MJ} \mathrm{MJ}^{-1}\right)^{\mathrm{b}}$ & - & $5.1210^{-2}$ \\
\hline Sodium hydroxide & - & $8.06 \times 10^{-5}$ \\
\hline Phosphoric acid & - & $5.38 \times 10^{-5}$ \\
\hline Presscake (output) ${ }^{c, d}$ & $5.2 \times 10^{-2}$ & $4.03 \times 10^{-2}$ \\
\hline \multicolumn{3}{|l|}{ Biodiesel plants } \\
\hline Rapeseed oil ${ }^{\mathrm{c}}$ & $2.71 \times 10^{-2}$ & $2.69 \times 10^{-2}$ \\
\hline Electricity input (MJ/MJ)a & $2.34 \times 10^{-3}$ & $1.84 \times 10^{-3}$ \\
\hline Thermal energy input $(\mathrm{MJ} / \mathrm{MJ})^{\mathrm{b}}$ & $2.77 \times 10^{-2}$ & $1.66 \times 10^{-2}$ \\
\hline Methanol & $3.58 \times 10^{-3}$ & $2.93 \times 10^{-3}$ \\
\hline Potassium hydroxide & $2.69 \times 10^{-4}$ & $2.69 \times 10^{-4}$ \\
\hline Sodium hydroxide & - & $8.06 \times 10^{-5}$ \\
\hline Sulphuric acid & $1.96 \times 10^{-4}$ & $1.7 \times 10^{-4}$ \\
\hline Hydrochloric acid & $2.69 \times 10^{-4}$ & - \\
\hline Biodiesel $^{c}$ & $2.69 \times 10^{-2}$ & $2.69 \times 10^{-2}$ \\
\hline Crude Glycerold & $3.47 \times 10^{-3}$ & $3.23 \times 10^{-3}$ \\
\hline FFA & $5.4 \times 10^{-4}$ & $2.69 \times 10^{-4}$ \\
\hline Fertiliser & $5.4 \times 10^{-4}$ & $2.69 \times 10^{-4}$ \\
\hline
\end{tabular}

${ }^{a}$ Electricity mix for Germany 2010 was taken from [100]

${ }^{\mathrm{b}}$ Thermal energy refers to German natural gas mix, taken from [101]

${ }^{c}$ Energetic allocation was carried out using the following lower heating values (LHV): press cake was taken to be $18.7 \mathrm{MJ} / \mathrm{kg}$, crude press oil $36 \mathrm{MJ} / \mathrm{kg}$ and biodiesel $37.2 \mathrm{MJ} / \mathrm{kg}$ biodiesel [102]

${ }^{\mathrm{d}}$ Output in italics refers to by-products. For this simple example, by products (except for press cake) were not considered; however, they are provided here to show the balances for each plant concept. Crude glycerol (approx. $80 \%$ glycerol)

was also assumed that there was no other demand for the rapeseed, other than biodiesel production.

\section{Step 5. NoRIMod-estimating emissions}

The key indirect emissions associated with biomass production and bioenergy conversion are outlined in Table 1. The relevant inventory assumptions are also provided in Tables 1 and 2 (see also Additional file 1, S.3). Flows relating to biomass production (inputs and emissions) were aggregated per catchment area and then divided by the amount of biomass used by the bioenergy plant (e.g., total $\mathrm{kg}$ rapeseed used per operational year). These catchment averages were then 
used as input flows for a rapeseed model developed in the life cycle software GaBi $6.0^{6}$, enabling the connection to be made with the upstream non-regional flows (e.g., fertiliser products). This was then linked to the relevant regional biodiesel models (Table 2) modelled in GaBi $6.0^{6}$ and coupled with Ecoinvent 2.2 inventory [104]. The resulting output of the modelling step was the aggregated emissions per functional unit of mega joule biodiesel produced. For the example presented here, GHG inventory results could be calculated for each configuration ${ }^{10}$.

\section{Output results}

The results of the RELCA simulations for the simple illustrative example indicate the overall regional average for producing $1 \mathrm{MJ}$ of biodiesel to be $35.4 \mathrm{~g} \mathrm{CO}_{2}$ eq. $\mathrm{MJ}^{-1}$. The regional emissions for the different biodiesel configurations ranged from 32.4-40.0 $\mathrm{g} \mathrm{CO}_{2}$ eq. $\mathrm{MJ}^{-1}$ (Fig. 4a). The cultivation step was found to contribute the majority of GHG emissions, ranging from between $65-80 \%$ of the total GHG emissions. The largest direct regional emissions were identified as coming from soil (e.g., $\mathrm{N}_{2} \mathrm{O}$ ) and the largest indirect GHG emissions associated with the production of nitrogen fertiliser (Fig. 4b).

Across the various catchments the share of direct emissions (i.e., those released directly in the region) were found to be between $37-42 \%$ of the total emissions, whereas, the indirect emissions (i.e., those released outside of the regional foreground) were found to be between $58-63 \%$ of the total emissions. Nitrogen fertiliser production contributed between $49-59 \%$ of the total indirect emissions. Energy production required to meet the thermal and electrical demands of the conversion plants contributing between 17-35\% of the total indirect emissions (non-regional).

Direct emissions from soil (e.g., $\mathrm{N}_{2} \mathrm{O}$ ) contributed between $84-87 \%$ of the total direct emissions, whereas, the other direct emissions in the simple example (e.g., exhaust emissions from field operations) contributed between $13-16 \%$. The distribution of the total direct GHG emissions per mega joule output for each biodiesel configurations can be seen in Fig. 5.

\section{Interpretation and discussion of example outputs}

Due to RELCA taking into account the regional and spatial variability of regional bioenergy production, it is not so easy to find comparable approaches in the literature, indeed as pointed out by Müller-Langer et al. [61], such direct comparisons between life cycle results should be done with care. However, one comparable study is that of Bernesson et al. [105]. They took regional averages to determine the potential GHG emissions associated with biodiesel production for a region in Sweden (cradleto-gate). They found GHG emissions to be between 39.5-40.3 gCO2eqMJ ${ }^{-1}$ for medium and small scale operations, respectively (using energetic allocation). Another bench mark comparator is the EU RED [106], which requires biodiesel to be produced with a GHG emission of less than $42 \mathrm{~g} \mathrm{CO}^{\mathrm{eq}} \mathrm{MJ}^{-1}$. Therefore, when comparing against these literature benchmarks, the RELCA results, for this example appear to be realistic and indicate that most biodiesel configurations presented in this simple example, have relatively better GHG performances.

The results of RELCA also indicate, as with other life cycle studies of biodiesel, that the cultivation of rapeseed contributes substantially to the overall GHG balance of biodiesel $[105,107,108]$. Therefore, the ability to determine

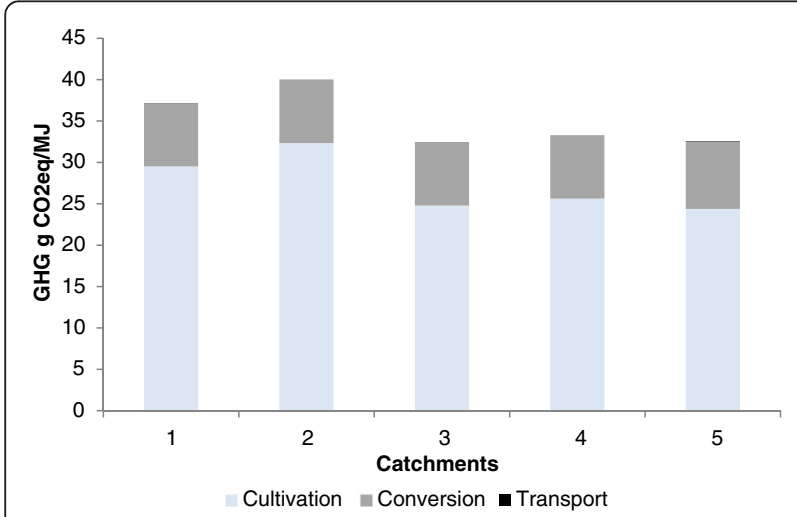

(a)

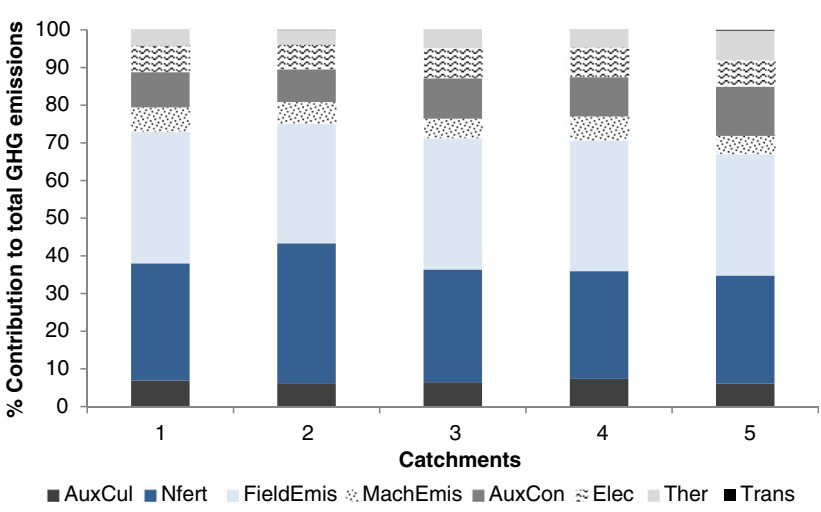

(b)

Fig. 4 a The GHG emission (g CO2eqMJ ${ }^{-1}$ ) for each process step associated with the regional bioenergy system, cultivation, conversion, and transport (to biodiesel plant) are shown for each of the five catchments included in the example case study. $\mathbf{b}$ The contribution of the different parameters to the total GHG emissions per mega joule of biodiesel. For meaning of abbreviations, refer to the list of abbreviations 


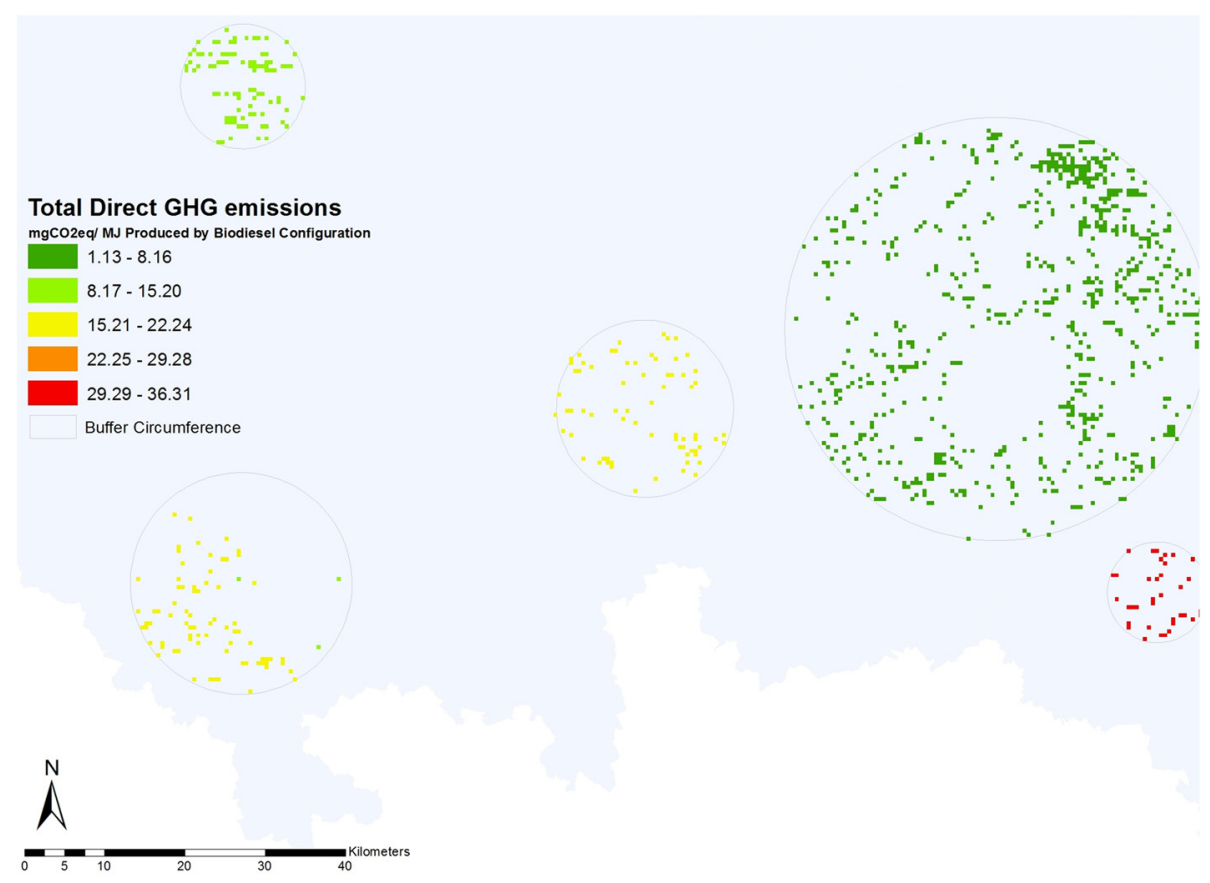

Fig. 5 Exemplary map to visualise the catchment delineated distributions of total direct $\mathrm{GHG}$ emissions (mg $\mathrm{CO}_{2}$ eq. $\mathrm{MJ}^{-1}$ ) for cultivation of rapeseed associated with the different biodiesel configurations within the example region. The variation for the different biodiesel configurations is dominated for this functional unit by the different installed capacities, with larger biodiesel configurations showing lower emissions per mega joule. However, greater spatial variation can be observed when looking at a map of emission intensity per hectare of supplied biomass (see Additional file 1, S.5). Map produced using Arc GIS ${ }^{\oplus}$ software by Esri

the GHG performance of the different biodiesel configurations and the regional variance of this performance is a critical component of the RELCA approach. The ability to do this is due to the more spatially detailed inventory for the production of the rapeseed feedstock. Indeed Malça et al. [108] in their review of GHG balances for European biodiesel chains identified more detailed modelling is required for soil emissions, such as $\mathrm{N}_{2} \mathrm{O}$, which are sensitive to the regional variability (e.g., fertiliser application, rotation) $[5,6,23,24,26-28]$. Such modelling advancements are crucial for improving the results of life cycle studies, and this is one of the objectives of the RELCA approach. For the simple example presented here, field emissions for rapeseed production were estimated by RELCA (v1.0), to range on average for the catchments from $3.02-4.66 \mathrm{~kg} \mathrm{~N}_{2} \mathrm{O} \mathrm{ha}{ }^{-1} \mathrm{a}^{-1}$. These values are within the ranges estimated in the literature for Eastern Germany of 1.9-14.8 $\mathrm{kg} \mathrm{N}_{2} \mathrm{O} \mathrm{ha}^{-1} \mathrm{a}^{-1}[39,109]$. However, the ability to validate such emissions is limited, as there is in general a lack of spatially distributed empirical studies which could enable an effective validation process [97], and this is a limitation of the RELCA approach. Therefore, it is important that the interpretation of RELCA results does not focus on the individual values themselves (e.g., for one particular catchment), but rather the ranges found throughout the entire region and across all bioenergy configurations. This discussion is continued further in the next section.

\section{Discussion}

\section{RELCA (v1.0) the first step}

With many burdens of bioenergy production strongly influenced by the regional and spatial variability (e.g., management, climate, soil) of biomass production $[5,6,23,24,26-28]$ more regional and spatially representative life cycle approaches for assessing bioenergy systems $[10,16,18,25]$ are required, to support the sustainable use of natural resources [11], such as biomass. The aim of this paper was to outline the challenges and options for developing a life cycle approach for assessing not only the regional environmental performance of bioenergy production, but also the spatial variability of that performance "within" a regional context [19].

As a first step, the ability to estimate GHG emissions for regional bioenergy systems has been used as a proof of concept, in order to show that adapting life cycle thinking to the "within regional context", as outlined by O'Keeffe et al. [19], can provide valuable insight into the potential regional and spatial variability (e.g., yields, nitrogen fertiliser, soils, climate) which may influence the environmental performance of regional bioenergy production. The RELCA approach is relatively straight 
forward with regard to integrating spatial data into a life cycle inventory accounting approach. It combines conventional geographical modelling with conventional life cycle software through the use of catchment delineation. RELCA is therefore, the first approach to explore catchment delineation as an option for including greater spatial details within a life cycle approach for bioenergy production. It has been shown here to work for the estimation of potential GHG balances (Additional file 1, S.3).

The result of the simple illustrative example helps to show how RELCA can work. It also indicates how the outputs can be used to explore the regional and spatial variation and how the emissions can change across and between the different catchments. This is mainly due to the different characteristics of the regional locations where biomass is produced (e.g., soils, climate, management) and due to the different characteristics of the different bioenergy plants (e.g., capacity and efficiency). This interaction in turn influences the final result of a bioenergy configuration (i.e., bioenergy plant and catchment) and thus, the overall potential GHG emissions associated with a regional bioenergy product. Therefore, as a retrospective scoping approach, RELCA can be used by policy makers to help first identify potential issues relating to regional bioenergy production e.g. production capacities too concentrated in one area. As well as helping to identify opportunities for improving regional bioenergy production, e.g., the need to adapt biomass management strategies for certain locations within the region due to relatively higher emissions. Furthermore, it can also help to identify areas or locations within the region which could benefit from more fundamental research, e.g., establishment of field trials for areas or soils which may be sensitive to greater emissions. The extent, to which this support can be given of course, depends on the quality of data acquired and robustness of modelling implemented for each of the modelling steps.

While RELCA (v1.0) proposed here is the first approach for assessing the environmental implications of regional bioenergy production and bioenergy configurations within a focus region, it is not without some practical drawbacks. These include time constraints, data availability at the required spatial resolutions, as well as the need to integrate different and complex datasets. Additionally, it is also important to consider the uncertainties in the interpretation and reporting of the RELCA results [110-114]. Both the biomass and bioenergy technology inventories will have their own unique sets of uncertainties, due to the broad spectrum of data sources and different disciplines used to derive such data. As mentioned previously for the biomass inventory, it will be difficult to validate the assumptions made for management practices and emissions, as empirical production and environmental data (i.e., farm surveys, field measurements) relating to biomass production are simply not monitored or measured at such spatial resolutions [48]. For bioenergy technology inventories, there are also no extensive or complete datasets available for cross checking, or comparison [69], making the validation of such results also challenging. Additional uncertainties and limitations, relate to the estimation of the NoRIMod indirect emissions, as many of these emission estimates are sourced from databases which may only provide generic or already pre-allocated values (see [84]). These uncertainties are not only relevant for bioenergy plant models, as many of the environmental burdens are indirect (i.e., upstream, non-regional), but also for biomass modelling, especially for the estimation of fertiliser production $[45,84]$. Furthermore, sensitivities to the underlying assumptions and modelling approaches implemented for estimating the potential environmental burdens or emissions should also be taken into account when interpreting the results of the approach. Therefore, the focus of the analysis should be on the potential ranges observed for the region and not on the individual results themselves, or for any one particular location. Contribution analysis and sensitivity analysis for parameters with a known higher level of uncertainty could also be used to help in the interpretation of the results $[110,112,114]$.

\section{Concept and design of RELCA-potential future developments}

The overall concept and design of RELCA is meant to be adaptable and flexible, thus enabling further complexity to be introduced in successive steps, with regards to the number of environmental burdens considered and spatiotemporal considerations (e.g., adapting crop rotations and land use). The current version of RELCA (v1.0) is unable, as of yet, to model additional environmental burdens, which lead to more regional and spatially dependent impacts, such as impacts to soil or water. There are two major challenges for this; the first relates to the need to integrate different spatial models in the regional foreground to assess for a greater number of burdens. The second relates to the development of NoRIMod approaches required to deal with the associated upstream non regional environmental burdens and linking them to the regional foreground environmental burdens.

Modelling the regional foreground is relatively straight forward when focusing on one set of emissions (e.g., GHGs); however, trying to combine two or more classification of emissions introduces greater complexity. This is particularly relevant when choosing the most appropriate spatial units and identifying which types of modelling approaches are compatible (e.g., which biophysical models can be combined) [19]. To date, there has been relatively little or no literature on the integration of different spatial models for determining different environmental burdens 
within life cycle approaches. There is also a lack of literature on how to handle the different spatial units required for the different modelling approaches (e.g., hydrological units for eutrophication emissions vs. simple square grids for GHG emissions). In general, singular approaches for estimating individual emission categories have been proposed $[24,115]$ and only one approach has been outlined for dealing with the uncertainties of using different spatial units for the full life cycle assessment [69]. Therefore, further research is needed to support the enhancement of more regionally distributed life cycle approaches, such as RELCA, which would enable them to include more than one potential environmental burden within a regional context.

Additionally, while RELCA can provide a static monitoring-based result for potential land occupation of certain biomass-to-bioenergy systems within the regional foreground, it cannot estimate the potential dLUC (direct land use change within the region) and iLUC (indirect land use change) occurring within and outside of the focus region. The use of more dynamic economic modelling approaches have been identified as the best means of estimating changes in land use, for example, equilibrium and agent-based modelling [116-118]. Such modelling can provide a better understanding of market interactions, which might lead to dLUC within a focus region or indeed lead to induced iLUC impacts outside the focus region. However, this is still an area which needs further consideration and indeed to model such related burdens and impacts, may require a different regional context, a more regionalized context (i.e., capturing interactions between regions) than that provided by RELCA (see [19]).

The current version of RELCA (v1.0) is at its simplest form for estimating GHG emissions, mainly because $\mathrm{GHG}^{10}$ burdens, due to their global impact potential, can be normalised to $\mathrm{CO}_{2}$ equivalents. This makes it easier to create links with life cycle software in the NoRIMod step. When it comes to estimating further environmental burdens (i.e., those relating to soil and water), this will require much greater effort to determine the associated non-regional upstream burdens. This includes, identifying all relevant non-regional upstream burdens from various different data sources and inventories, e.g., Ecoinvent, GEMIS, $\mathrm{CML}^{6}$ (i.e., which emissions need to be included and to which tier), as well as organising and structuring the data flows, in order to integrate them into the rest of the RELCA modelling approach. This in the end could be very time consuming, it may also require the modification of the life cycle matrices.

Additionally, while RELCA in its current iteration is designed to conduct a life cycle inventory assessment, efforts should still be made during the development of the inventory, to enable the future possibility of linking to plausible and robust impact assessment methods (i.e., adding an LCIA phase to account for impacts to water, soil, or biodiversity). However, many challenges have been identified with regards to turning the potential environmental burdens (LCI) derived in a spatially distributed manner, into potential impacts (LCIA) for a regionally contextualised approach. The ability to do this will depend on the availability of characterisation factors at the appropriate scale, or indeed the ability to calculate a chosen impact or impacts through direct modelling, e.g., fate and transport models or land-use models [19]. Therefore, further research into this possible development of RELCA is also required.

Despite the limitations of the current version, RELCA (v.1.0) is the first step towards materialising a regional and spatial life cycle approach for assessing the environmental implications of bioenergy production and bioenergy configurations (e.g., bioenergy plants and catchments) within a focus region. It also provides a good starting point for further discussion, improvements and modelling developments for assessing the regional and spatial environmental implications of bioenergy production (e.g., such as impacts to soil, water, and biodiversity) for a within regional context.

\section{Conclusions}

Life cycle thinking is ever increasingly being used in various sustainable development policies and to support how environmental issues and decisions are deliberated and handled $[119,120]$. This is exceedingly the case for bioenergy and as decision makers work in real time and cannot wait for precise results, there is a demand on life cycle approaches to simplify complex systems. $[10,119]$ This is what the RELCA approach sets out to do. The regional life cycle inventory assessment (RELCA) outlined in this paper is the first approach to assess not only the regional environmental performance of bioenergy production, but also the spatial variability of that performance "within" a regional context. It does this through combining conventional geographical modelling with conventional life cycle software through the use of catchment delineation. RELCA is therefore, the first approach to explore catchment delineation as an option for including greater spatial details within a life cycle approach for bioenergy production. It has been shown here to work for the estimation of the potential GHG performance of a regional bioenergy product. However, RELCA (v1.0) is not without its limitations. Despite these, it still provides a good starting point for further discussion, improvements and modelling developments for assessing the more regional and spatial environmental implications of bioenergy production (e.g., such as impacts to soil, water and biodiversity) for a within regional context. Indeed, with a greater emphasis being placed on the role of biomass in supporting a future 
bioeconomy, (i.e., the use of biomass resources for the production of food, materials, chemicals, fuels and energy) $[121,122]$, the development of approaches, such as RELCA, will be necessary for the sustainable management of natural resources, such as biomass.

\section{Endnotes}

${ }^{1}$ We refer to burdens here as environmental interventions e.g., emissions and resource use. We use environmental burdens and emissions interchangeably.

${ }^{2}$ We use the term life cycle thinking here to refer to life cycle concepts, ideas that extend the life cycle towards a more system based approach [123].

${ }^{3}$ The definition of a region was that used by Loiseau et al. (2012) [12] which is, "a region is a spatial scale below a nation, usually including two or more communities with naturally or arbitrary determined boundaries, and which covers from tens to thousands of kilometres".

${ }^{4}$ For more information on aspects of the life cycle impact assessment phase for the different regional contexts, please refer to [19].

${ }^{5}$ Data can be transferred between the different modelling tools through the use of text files either as, delineated (.txt) or comma separated values (.csv), which can be used as input/output files.

${ }^{6}$ Matlab (The MathWorks, Inc., Natick, Massachusetts, United States); R (Core Team (2012). R: A language and environment for statistical computing. R Foundation for Statistical Computing, Vienna, Austria. ISBN 3-900051-070;Aspen Plus ${ }^{\circ}$. Aspen Technology, Inc.; PE.GaBi Software Systems and Databases for Life Cycle Engineering. Copy right TM. Stuttgart,Echerdingen 1992-2016; SimaPro Life Cycle Analysis (software), Pre Consultants bv. Printerweg 1838421 AD Amersfoort, The Netherlands; Open LCA, Green Delta GmbH (http://www.openlca.org/).GEMIS Global Emissions Model for integrated Systems, International Institute for Sustainability Analysis and Strategy (IINAS), Darmstadt, Germany (http://www.iinas.org/gemis.html); CML, Leiden University, the Netherlands.

${ }^{7}$ MAUP a fundamental geographical problem endemic to all studies of spatially aggregated data, arising from the need to model or describe continuous spatial phenomena with discrete geographic units. For more information on the issues of MAUP refer to [44, 124].

${ }^{8}$ Active ingredients are the key chemical constituents present (e.g., Metazachlor, Tebucaonazol) in the crop protection product applied which effectively act to protect the crop, for more insight please refer to $[125,126]$.

${ }^{9}$ For more complex NoRIMod approaches read supplementary material, for ease of flow this was not put in the main paper, as some background calculation theory had to be provided.

${ }^{10}$ Technically converting all emissions to $\mathrm{CO}_{2}$ equivalents is a characterisation step performed in the LCIA phase of LCA, we use it here to simplify the summation of the LCI, as is common practice in life cycle approaches. Additionally GHGs are classified as regional burdens with global impacts [127] and are site generic [128], therefore summation of these emissions in a GHG category is permissible in a regional distributed, as there is no need to have a regionally distributed impact assessment.

${ }^{11}$ The "Ackerzahl" values are used in Germany to provide an estimate of agricultural productivity. They are derived from information relating to an areas soil fertility, slope, elevation and the climate of a particular site. A value below 30 indicates low productivity, with a value of 100 being the most productive [90].

\section{Additional file}

Additional file 1: Supplimentary material- RELCA. (PDF 304 kb)

\section{Abbreviations}

AuxCon: auxiliaries associated with the conversion of biomass to biodiesel (e.g., methanol, hydroxide)—non-regional emissions; AuxCul: cultivation auxiliaries (which are not nitrogen fertiliser e.g., pesticides, diesel other fertilisers); BioMod: biomass management modelling; CAMod: catchment allocation modelling; CAN: calcium ammonium nitrate- $\mathrm{N}$ fertiliser;

$\mathrm{CH}_{4}$ : methane-gaseous emission; $\mathrm{CO}_{2}$ : carbon dioxide—gaseous emission; CPMod: conversion plant modelling; CRAMod: crop allocation modelling; Elec: electrical energy —non-regional emissions from the German national grid; ERSI: environment rating scales institute; FieldEmis: field emissions, here modelled only for $\mathrm{N}_{2} \mathrm{O}$ (direct regional emissions); FORTRAN: formula translating system —a programming language; GHG: greenhouse gas emissions; GIS: geographical Information systems; ILCD: international reference life cycle data system; IPCC: international panel on climate change; KLM: keyhole mark-up language; LCl: life cycle inventory; LCIA: life cycle impact assessment; MachEmis: exhaust emissions associated with agricultural machinery used for the biomass production—direct emissions; MAUP: modifiable areal unit problem; $\mathrm{N}_{2} \mathrm{O}$ : nitrous oxide — gaseous emission; Nfert: nitrogen fertiliser. Emissions are associated with the production of the regional mix, assumed to be external to the region; NMVOC: non methane volatile organic compounds; NoRIM: non-regional inventory modelling; RELCA: A regional life cycle inventory for assessing bioenergy systems in a within regional context; $\mathrm{SF}_{6}$ : sulphur hexafluoride; Ther: thermal energy — non-regional emissions from natural gas used in generating thermal energy; Trans: transport-exhaust pipe emissions (direct); UAN: urea ammonium nitrate fertiliser.

\section{Competing interests}

The authors declare that they have no competing interests.

\section{Author's contribution}

SOK developed the RELCA approach, drafted and wrote the paper. SWM developed the CRAM model, supported the RELCA approach, and contributed to the manuscript; DT supported the RELCA approach and contributed to the manuscript. All authors read and approved the final manuscript.

\section{Acknowledgements}

This work was made possible by funding from the Helmholtz Association of German Research Centres within the project funding "Biomass and Bioenergy Systems". The authors would like to thank our colleagues at the DBFZ (German Biomass Research (entre) for their support in the development of conversion plant models. We would also like to thank the German weather service (DWD) for the provision of meteorological data. Additionally the authors would also like to thank the reviewers for the time they spent reviewing the manuscript and for their thorough feedback which has helped to improve the quality of the paper. This paper was submitted as part of the contributions to the "Biomass for energy-lessons from the Bioenergy Boom" workshop (24-25 November 2014, Leipzig). 


\section{Author details}

'Department of Bioenergy, Helmholtz-Zentrum für Umweltforschung (UFZ) GmbH, Permoserstraße 15, 04318 Leipzig, Germany. ${ }^{2}$ DBFZ, GmbH, Torgauer Straße 116, 04347 Leipzig, Germany.

\section{Received: 29 July 2015 Accepted: 12 April 2016 \\ Published online: 18 May 2016}

\section{References}

1. FNR (2014) Fachagentur Nachwachsende Rohstoffe e.V. Bioenergy in Germany: facts and figures. Available at: http://mediathek.fnr.de/media/ downloadable/files/samples/b/a/basisdaten_9x16_2013_engl_web.pdf. Accessed Mar 2014

2. DBFZ (2011) Deutsches Biomasse Forschungs Zentrum, Monitoring zur Wirkung des Erneuerbare-Energien- Gesetz (EEG) auf die Entwicklung der Stromerzeugung aus Biomasse

3. Naumann K, Oehmichen K, Zeymer M, Meisel K (2014) Monitoring Biokraftstoffsektor. In: Nelles M (ed) DBFZ-Report Nr. 11, 2. Auflage. DBFZ, Leipzig

4. Sauerbrei R, Ekschmitt K, Wolters V, Gottschalk TK (2014) Increased energy maize production reduces farmland bird diversity. GCB Bioenergy 6(3):265-274

5. Brandão M, Milà I, Canals L, Clift R (2011) Soil organic carbon changes in the cultivation of energy crops: Implications for GHG balances and soil quality for use in LCA. Biomass Bioenergy 35(6):2323-2336. doi:10.1016/j.biombioe. 2009.10.019

6. Fernando AL, Duarte MP, Almeida J, Boléo S, Mendes B (2010) Environmental impact assessment of energy crops cultivation in Europe. Biofuel Bioprod Bior 4(6):594-604. doi:10.1002/bbb.249

7. Delucchi MA (2010) Impacts of biofuels on climate change, water use, and land use. Ann. N.Y. Acad. Sci 1195(1):28-45. doi:10.1111/j.1749-6632.2010.05457.x

8. Havlík P, Schneider UA, Schmid E, Böttcher H, Fritz S, Skalský R, Aoki K, Cara SD, Kindermann G, Kraxner F, Leduc S, McCallum I, Mosnier A, Sauer T, Obersteiner M (2011) Global land-use implications of first and second generation biofuel targets. Energy Policy 39(10):5690-5702. doi:10.1016/ j.enpol.2010.03.030

9. Cherubini F, Bird ND, Cowie A, Jungmeier G, Schlamadinger B, Woess-Gallasch S (2009) Energy- and greenhouse gas-based LCA of biofuel and bioenergy systems: Key issues, ranges and recommendations. Resour Conserv Recy 53(8):434-447. doi:10.1016/j.resconrec.2009.03.013

10. McKone TE, Nazaroff WW, Berck P, Auffhammer M, Lipman T, Torn MS, Masanet E, Lobscheid A, Santero N, Mishra U, Barrett A, Bomberg M, Fingerman K, Scown C, Strogen B, Horvath A (2011) Grand challenges for life-cycle assessment of biofuels. Environ Sci Technol 45(5):1751-1756. doi:10.1021/es103579c

11. COM (2005) 670 Communication from the Commission of 21 December 2005, Thematic Strategy on the sustainable use of natural resources

12. Loiseau E, Junqua G, Roux P, Bellon-Maurel V (2012) Environmental assessment of a territory: an overview of existing tools and methods. J Environ Manage 112:213-225

13. van der Hilst F, Lesschen JP, van Dam JMC, Riksen M, Verweij PA, Sanders JPM, Faaij APC (2012) Spatial variation of environmental impacts of regional biomass chains. Renew Sust Energ Rev 16(4):2053-2069. doi:10.1016/j.rser.2012.01.027

14. Hoffmann D (2009) Creation of regional added value by regional bioenergy resources. Renew Sustain Energy Rev 13(9):2419-2429. doi:10.1016/j.rser.2009.04.001

15. O'Keeffe S, Wochele S, Thrän D (2013) Regional Bioenergy Inventory for the Central Germany Region. In: Geldermann J, Schumann M (eds) First International Conference on Resource Efficiency in Interorganizational Networks - ResEff 2013: November 13th-14th, 2013 Georg-AugustUniversität Göttingen, Papers. Niedersächsische Staats- und Universitätsbibliothek

16. Gasol CM, Gabarrell X, Rigola M, González-García S, Rieradevall J (2011) Environmental assessment: (LCA) and spatial modelling (GIS) of energy crop implementation on local scale. Biomass and Bioenergy 35(7):2975-2985. doi:10.1016/j.biombioe.2011.03.041

17. Geyer R, Lindner JP, Stoms DM, Davis FW, Wittstock B (2010) Coupling GIS and LCA for biodiversity assessments of land use: part 2: impact assessment. Int J LCA 15(7):692-703, doi:10.1007/s11367-010-0199-9

18. Geyer R, Stoms D, Kallaos J (2012) Spatially-explicit life cycle assessment of Sun-to-wheels transportation pathways in the U.S. Environ Sci Technol 47(2):1170-1176. doi:10.1021/es302959h
19. O'Keeffe S, Majer S, Bezama A, Thrän D (2016) When considering no man is an island-assessing bioenergy systems in a regional and LCA context: a review. Int J LCA: 1-18. doi:10.1007/s11367-016-1057-1

20. Heijungs R, Suh S (2002) The computational structure of life cycle assessment. Kluwer Academic Publishers, Dordrecht

21. Heijungs R (2012) Spatial differentiation, GIS-based regionalization, hyperregionalization, and the boundaries of LCA. In: Ge I (ed) Environment and energy: editorial series of Italian commodity science academy and engineering association of Messina. Franco Angeli, Milano, Italy, pp 165-176

22. Owens JW (1997) Life-Cycle Assessment: Constraints on Moving from Inventory to Impact Assessment. J Ind Ecol 1:37-49 doi:10.1162/jiec.1997.1.1.37

23. Curtright $A E$, Johnson DR, Willis HH, Skone T (2012) Scenario uncertainties in estimating direct land-use change emissions in biomass-to-energy life cycle assessment. Biomass and Bioenergy 47(0):240-249. doi:10.1016/ j.biombioe.2012.09.037

24. Dufossé K, Gabrielle B, Drouet JL, Bessou C (2013) Using agroecosystem modeling to improve the estimates of $\mathrm{N} 2 \mathrm{O}$ emissions in the life-cycle assessment of biofuels. Waste Biomass Valorization 4(3):593-606. doi:10.1007/s12649-012-9171-1

25. Geyer R, Lindner J, Stoms D, Davis F, Wittstock B (2010) Coupling GIS and LCA for biodiversity assessments of land use. Int J LCA 15(5):454-467. doi:10.1007/s11367-010-0170-9

26. Adler PR, Grosso SJD, Parton WJ (2007) Life Cycle Assessment of net greenhouse-gas flux for bioenergy cropping systems. Ecol Appl 17(3):675-691. doi:10.1890/05-2018

27. Crutzen P, Mosier AR, Smith KA, Winiwater W (2008) N2O release from agro-biofuel production negates global warming reduction by replacing fossil fuels. Atmos Chem Phys 8:389-395

28. Kim S, Dale B (2009) Regional variations in greenhouse gas emissions of biobased products in the United States-corn-based ethanol and soybean oil. Int J LCA 14(6):540-546. doi:10.1007/s11367-009-0106-4

29. EC-JRC (2010) General Guide for Life Cycle Assessments: Detailed guidance. ILCD handbook- International Reference Life Cycle Data System, European Union. Available at: http://bookshop.europa.eu/en/international-referencelife-cycle-data-system-ilcd-handbook-pbLBNA24708/. Accessed Jan 2012

30. Cherubini F, Strømman AH (2011) Life cycle assessment of bioenergy systems: state of the art and future challenges. Bioresour Technol 102(2):437-451. doi:10.1016/j.biortech.2010.08.010

31. Wochele S, Priess J, Thrän D, O'Keeffe S (2014) Crop allocation model "CRAM" - an approach for dealing with biomass supply from arable land as part of a life cycle inventory. In: Hoffmann C, Baxter D, Maniatis K, Grassi A, Helm P (eds) EU BC\&E Proceedings 2014. ETA-Florence Renewable Energies, Florence, pp 36-40

32. Roeder N, Osterburg B (2012) The impact of map and data resolution on the determination of the agricultural utilisation of organic soils in Germany. Environ Manage 49(6):1150-1162. doi:10.1007/s00267-012-9849-y

33. Castellazzi MS, Matthews J, Angevin F, Sausse C, Wood GA, Burgess PJ, Brown I, Conrad KF, Perry JN (2010) Simulation scenarios of spatio-temporal arrangement of crops at the landscape scale. Environ Model Softw 25(12):1881-1889. doi:10.1016/j.envsoft.2010.04.006

34. Happe K, Kellerman K, Balmann A (2006) Agent-based analysis of agricultural policies: an illustration of the agricultural policy simulator AgriPoliS, its adaptation and behavior. Ecol Soc 11(1):49

35. Cobuloglu HI, Büyüktahtakın IE (2015) Food vs. biofuel: an optimization approach to the spatio-temporal analysis of land-use competition and environmental impacts. Applied Energy 140(0):418-434. doi:10.1016/ j.apenergy.2014.11.080

36. Li M, Guo P (2015) A coupled random fuzzy two-stage programming model for crop area optimization - a case study of the middle Heihe River basin, China. Agric Water Manage 155(0):53-66. doi:10.1016/j.agwat.2015.03.013

37. Vázquez-Rowe I, Marvuglia A, Flammang K, Braun C, Leopold U, Benetto E (2014) The use of temporal dynamics for the automatic calculation of land use impacts in LCA using R programming environment. Intl J LCA 19(3):500-516. doi:10.1007/s11367-013-0669-y

38. CLC (2006) CORINE Land Cover (CLC2006); Federal Environment Agency, DLR-DFD 2009.

39. Haas E, Klatt S, Fröhlich A, Kraft P, Werner C, Kiese R, Grote R, Breuer L, Butterbach-Bahl K (2013) LandscapeDNDC: a process model for simulation of biosphere-atmosphere-hydrosphere exchange processes at site and regional scale. Landscape Ecol 28(4):615-636. doi:10.1007/ s10980-012-9772-x 
40. Phillips DL, Marks DG (1996) Spatial uncertainty analysis: propagation of interpolation errors in spatially distributed models. Ecol Model 91(1-3):213-229. doi:10.1016/0304-3800(95)00191-3

41. Pfister S, Koehler A, Hellweg S (2009) Assessing the environmental impacts of freshwater consumption in LCA. Environ Sci Technol 43(11):4098-4104. doi:10.1021/es802423e

42. Heuvelmans G, Garcia-Qujano JF, Muys B, Feyen J, Coppin P (2005) Modelling the water balance with SWAT as part of the land use impact evaluation in a life cycle study of $\mathrm{CO} 2$ emission reduction scenarios. Hydrol Process 19(3):729-748. doi:10.1002/hyp.5620

43. Nansai K, Moriguchi Y, Suzuki N (2005) Site-dependent life-cycle analysis by the SAME approach: its concept, usefulness, and application to the calculation of embodied impact intensity by means of an input-output analysis. Environ Sci Technol 39(18):7318-7328. doi:10.1021/es047951n

44. Openshaw (1983) The Modifiable Area Unit Problem. Concepts and techniques in modern geography no 38. Available at: https://www.uio.no/ studier/emner/sv/iss/SGO9010/openshaw1983.pdf. Accessed: Apr 2014

45. Erisman J, Grinsven H, Leip A, Mosier A, Bleeker A (2010) Nitrogen and biofuels; an overview of the current state of knowledge. Nutr Cycl Agroecosyst 86(2):211-223. doi:10.1007/s10705-009-9285-4

46. Popp $\mathrm{A}$, Lotze-Campen $\mathrm{H}$, Leimbach $\mathrm{M}$, Knopf $\mathrm{B}$, Beringer $\mathrm{T}$, Bauer $\mathrm{N}$, Bodirsky B (2011) On sustainability of bioenergy production: Integrating co-emissions from agricultural intensification. Biomass Bioenergy 35(12):4770-4780. doi:10.1016/j.biombioe.2010.06.014

47. Smeets EMW, Bouwman LF, Stehfest E, Van Vuuren DP, Posthuma A (2009) Contribution of $\mathrm{N} 2 \mathrm{O}$ to the greenhouse gas balance of first-generation biofuels. Glob Chang Biol 15(1):1-23. doi:10.1111/j.1365-2486.2008.01704.x

48. Nemecek T, Erzinger S (2005) Modelling representative life cycle inventories for swiss arable crops (9 pp). Int J LCA 10(1):68-76. doi:10.1065/lca2004.09.181.8

49. O'Keeffe S, Schulte RPO, Sanders JPM, Struik PC (2011) I. Technical assessment for first generation green biorefinery (GBR) using mass and energy balances: scenarios for an Irish GBR blueprint. Biomass and Bioenergy 35(11):4712-4723. doi:10.1016/j.biombioe.2011.06.017

50. Del Grosso SJ, Mosier AR, Parton WJ, Ojima DS (2005) DAYCENT model analysis of past and contemporary soil $\mathrm{N} 2 \mathrm{O}$ and net greenhouse gas flux for major crops in the USA. Soil Till Res 83(1):9-24. doi:10.1016/j. still.2005.02.007

51. Brentrup F, Küsters J, Lammel J, Barraclough P, Kuhlmann H (2004) Environmental impact assessment of agricultural production systems using the life cycle assessment (LCA) methodology II. The application to N fertilizer use in winter wheat production systems. Euro J Agron 20(3):265-279. doi:10.1016/S1161-0301(03)00039-X

52. Brunotte J, Wagner M, Sommer C (2001) Bodenschutz und Kosteneinsparung Anforderungen an heutige Bodenbearbeitung. Landtechnik 56(3):2. doi:10.15150/lt.2001.1729

53. IPCC (2006) Guidelines for National Greenhouse Gas Inventories. Intergovernmental Panel of Climate Change (IPCC), National Greenhouse Gas Inventories Programme. Online at: http://www.ipcc-nggip.iges.or.jp/ public/2006gl/. Accessed: Jan 2012

54. Li C, Frolking S, Frolking TA (1992) A model of nitrous oxide evolution from soil driven by rainfall events: 1. Model structure and sensitivity. J Geophys Res-Atmos 97(D9):9759-9776. doi:10.1029/92jd00509

55. Butterbach-Bahl K, Kesik M, Miehle P, Papen H, Li C (2004) Quantifying the regional source strength of $\mathrm{N}$-trace gases across agricultural and forest ecosystems with process based models. Plant Soil 260(1-2):311-329. doi:10. 1023/B:PLSO.0000030186.81212.fb

56. Leip A, Busto M, Winiwarter W (2011) Developing spatially stratified N2O emission factors for Europe. Environ Pollut 159(11):3223-3232. doi:10.1016/j.envpol.2010.11.024

57. Kim S, Dale BE (2005) Environmental aspects of ethanol derived from notilled corn grain: nonrenewable energy consumption and greenhouse gas emissions. Biomass and Bioenergy 28(5):475-489. doi:10.1016/j.biombioe. 2004.11.005

58. Guo M, Li C, Bell JNB, Murphy RJ (2011) Influence of agro-ecosystem modeling approach on the greenhouse gas profiles of wheat-derived biopolymer products. Environ Sci Technol 46(1):320-330. doi:10.1021/es2030388

59. Goglio P, Grant BB, Smith WN, Desjardins RL, Worth DE, Zentner R, Malhi SS (2014) Impact of management strategies on the global warming potential at the cropping system level. Sci Total Environ 490(0):921-933. doi:10.1016/j.scitotenv.2014.05.070
60. Sarkar S, Miller SA, Frederick JR, Chamberlain JF (2011) Modeling nitrogen loss from switchgrass agricultural systems. Biomass and Bioenergy 35(10):4381-4389. doi:10.1016/j.biombioe.2011.08.009

61. Muller-Langer F, Majer S, O'Keeffe S (2014) Benchmarking biofuels-a comparison of technical, economic and environmental indicators. Energy Sustain Soc 4(1):20

62. Ciroth A, Hagelüken M, Sonnemann G, Castells F, Fleischer G (2002) Geographical and technological differences in life cycle inventories shown by the use of process models for waste incinerators. Int J LCA 7(6):363-368. doi:10.1007/bf02978685

63. Ciroth A, Hagelüken M, Sonnemann G, Castells F, Fleischer G (2002) Geographical and technological differences in life cycle inventories shown by the use of process models for waste incinerators part I. technological and geographical differences. Int J LCA 7(5):295-300. doi:10.1007/bf02978891

64. Ponitka, P, Arendt O, Lenz V, Daniel-Gromke J, Stinner W, Ortwein A, Zeymer M, Gröngröft A, Müller-Langer F, Klemm, M, Braun J, Thrän D, O'Keeffe S, Millinger M (2015) Konversionspfade - zur energetischen Biomassenutzung im 21. Jahrhundert. In Thrän D, Ponitka J, Arendt O. (eds): Focus on: Bioenergie-Technologien. Leipzig - ISSN 2192-1156. Available at: https:// www.energetische-biomassenutzung.de/fileadmin/user_upload/Downloads/ Ver\%C3\%B6ffentlichungen/fh_technologie_web_small.pdf. Accessed: Jan 2016.

65. Biofuelwatch (2015) UK Bioenergy Maps. Available at: https://docs.google.com/ spreadsheets/d/1YSC3gjXwJx7zChDVTPTUJF2tqS9OgjufS4_KZ4AV2ss/pub. Accessed 21 May 2015

66. NREL (2015) The Biofuels Atlas. Available at: https://maps.nrel.gov/biofuelsatlas/\#/?activeLayers=5mt9DT\&baseLayer=groad\&mapCenter $=40.21244 \% 2 \mathrm{C}$ 91.625976\&zoomLevel=4. Accessed 21 May 2015

67. >Sundaravaradan N, Marwah M, Shah A, Ramakrishnan N Data mining approaches for life cycle assessment. In: Proceedings of the 2011 IEEE International Symposium on Sustainable Systems and Technology, 16-18 May 2011 2011. pp 1-6. doi:10.1109/issst.2011.5936863

68. Das S, Eichhorn M, Hoffgarten VM, Lang E, Priess JA, Thraen D (2012) Spatial analysis of the potential of district heating from existing bioenergy installations in Germany. In: EU BC\&E. 20th European Biomass Conference and Exhibition, Italy

69. Mutel CL, Pfister S, Hellweg S (2011) GIS-based regionalized life cycle assessment: how big is small enough? Methodology and case study of electricity generation. Environ Sci Technol 46(2):1096-1103. doi:10.1021/es203117z

70. Dresen B, Jandewerth M (2012) Integration of spatial analyses into LCA — calculating GHG emissions with geoinformation systems. Int J LCA 17(9):1094-1103. doi:10.1007/s11367-011-0378-3

71. Scheffran J, BenDor T, Wang Y, Hannon B (2007) A Spatial-Dynamic Model of Bioenergy Crop Introduction in Illinois. In Proceedings of the 25th International Conference of the System Dynamics Society. Boston July 29 August 2. Available at: http://www.systemdynamics.org/conferences/2007/ proceed/papers/BENDO452.pdf. Accessed: Mar 2012.

72. Thomas A, Bond A, Hiscock K (2013) A GIS based assessment of bioenergy potential in England within existing energy systems. Biomass and Bioenergy 55(0):107-121. doi:10.1016/j.biombioe.2013.01.010

73. Overend RP (1982) The average haul distance and transportation work factors for biomass delivered to a central plant. Biomass 2(1):75-79. doi:10.1016/0144-4565(82)90008-7

74. Leboreiro J, Hilaly AK (2011) Biomass transportation model and optimum plant size for the production of ethanol. Bioresour Technol 102(3):2712-2723. doi:10.1016/j.biortech.2010.10.144

75. Dunnett A, Adjiman C, Shah N (2008) A spatially explicit whole-system model of the lignocellulosic bioethanol supply chain: an assessment of decentralised processing potential. Biotechnol Biofuels 1(1):13

76. Sultana A, Kumar A (2012) Optimal siting and size of bioenergy facilities using geographic information system. Appl Energy 94(0):192-201. doi:10.1016/j.apenergy.2012.01.052

77. Monforti F, Bódis K, Scarlat N, Dallemand JF (2013) The possible contribution of agricultural crop residues to renewable energy targets in Europe: a spatially explicit study. Renew Sust Energ Rev 19(0):666-677. doi:10.1016/j.rser.2012.11.060

78. Bernesson S, Nilsson D, Hansson P-A (2006) A limited LCA comparing largeand small-scale production of ethanol for heavy engines under Swedish conditions. Biomass Bioenergy 30(1):46-57. doi:10.1016/j.biombioe.2005.10.002

79. Walla C, Schneeberger W (2008) The optimal size for biogas plants. Biomass Bioenergy 32(6):551-557. doi:10.1016/j.biombioe.2007.11.009 
80. Azapagic A, Pettit C, Sinclair P (2007) A life cycle methodology for mapping the flows of pollutants in the urban environment. Clean Technol Environ 9(3):199-214. doi:10.1007/s10098-007-0092-9

81. Saner D, Vadenbo C, Steubing B, Hellweg S (2014) Regionalized LCA-based optimization of building energy supply: method and case study for a swiss municipality. Environ Sci Technol 48(13):7651-7659. doi:10.1021/es500151q

82. Majer S, Gröngröft A (2010) Environmental and economic assessment of biomethanol for the biodiesel production. Short study. Deutschs Biomass Forschuns Zentrum (DBFZ) http://www.ufop.de/files/4613/3940/7473/20101026_ DBFZ_Kurzstudie_Biomethanol_eng.pdf. Accessed March 2011.

83. Majer S, Mueller-Langer F, Zeller V, Kaltschmitt M (2009) Implications of biodiesel production and utilisation on global climate-a literature review. Eur J Lipid Sci Technol 111(8):747-762. doi:10.1002/ejlt.200900045

84. Müller-Langer F, Gröngröft A, Majer S, O'Keeffe S, Klemm M (2013) Options for biofuel production - status and perspectives. In: Transition to Renewable Energy Systems. Wiley-VCH Verlag GmbH \& Co. KGaA, pp 523-553. doi:10.1002/9783527673872.ch26

85. Caserini S, Livio S, Giugliano M, Grosso M, Rigamonti L (2010) LCA of domestic and centralized biomass combustion: the case of Lombardy (Italy). Biomass Bioenergy 34(4):474-482. doi:10.1016/ j.biombioe.2009.12.011

86. Johansson LS, Tullin C, Leckner B, Sjövall P (2003) Particle emissions from biomass combustion in small combustors. Biomass Bioenergy 25(4):435-446. doi:10.1016/S0961-9534(03)00036-9

87. Pa A, Bi XT, Sokhansanj S (2011) A life cycle evaluation of wood pellet gasification for district heating in British Columbia. Bioresour Technol 102(10):6167-6177. doi:10.1016/j.biortech.2011.02.009

88. ISO 14044 (2006) Environmental management-life cycle assessment-requirements and guidelines. international standard. International Organisation of Standardisation, Geneva

89. BÜK 1000 (2007) Soil Map of Germany 1:1.000.000 (BÜK 1000) (2007) Source: Federal Institute for Geosciences and Natural Resources

90. Scheffer F, Schachtschabel P (2002) Lehrbuch der Bodenkunde, 15th edn. Spektrum Akademischer Verlag GmbH, Heidelberg, p 593 S

91. Federal Statistical Office Germany GENESIS Database.https://wwwgenesis destatis.de/genesis/online/logon. Accessed 2013

92. Holz F, Weigel U, Kuhn K (1999) Grundlagen der Düngebedarfsermittlung für eine gute fachliche raxis beim Düngen. LUFA Sachsen. Available at: http://www.llg.sachsen-anhalt.de/ackerbau-und-pflanzenbau/ pflanzenernaehrung-und-duengung/basisinformationen/. Accessed: Apr 2014

93. KTBL (2012) Leistungs-Kostenrechnung Pflanzenbau. Available at: http://daten.ktbl.de/dslkrpflanze/postHv.htm|\#Auswahl. Accessed: Nov 2012

94. VDLUFA (2000) Verband Deutscher Landwirtschaftlicher Untersuchungsund Forschungsanstalten. Bestimmung des Kalkbedarfs von Acker- und Grünlandböden

95. Rösemann C, Haenel HD, Poddey E, Dämmgen U, Döhler H, Eurich-Menden B, Laubach P, Dieterle M, Laubach P, Osterburg B (2011) Calculations of gaseous and particulate emissions from German agriculture 1990-2009. Berechnung von gas- und partikelförmigen Emissionen aus der deutschen Landwirtschaft 1990-2009. Landbauforschung, Sonderheft 342

96. IPCC (2006) IPCC Guidelines for National Greenhouse Gas Inventories, prepared by the National Greenhouse Gas Inventories Programme, edited by: Eggleston, H.S, Buendia, L., Miwa, K., Ngara, T. and Tanabe, K., Volume 4, Chapter 11, N2O emissions from managed soils, and CO2 emissions from lime and urea application, IGES, Hayama, Japan

97. Brocks S, Jungkunst HF, Bareth G. (2014) A regionally disaggregated inventory of nitrous oxide emissions from agricultural soils in Germany-A GIS based empirical approach. ERDKUNDE:125-144

98. Bundesamt S (2011) Düngemittelversorgung Wirtschaftsjahr 2010/2011, Wiesbaden. Available at: https://www.destatis.de/DE/Publikationen/ Thematisch/IndustrieVerarbeitendesGewerbe/Fachstatistik/ DuengemittelversorgungJ2040820127004.html. Accessed Apr 2013

99. Spielmann M, Bauer C, Dones R, Tuchschmid M (2007) Transport services: Ecoinvent report no. 14. Swiss Centre for Life Cycle Inventories, Dübendorf

100. Thrän D. and Pfeiffer D., (Eds.) Method handbook-material flow-oriented assessment of greenhouse gas effects. In: Series of the funding programme "Biomass energy use", Vol. 04, Leipzig - ISSN online - 2364-897X. 2015.

101. Dones R, Bauer C, Bolliger R, Burger B, Faist Emmenegger M, Frischknecht R, Heck T, Jungbluth N, Röder A, Tuchschmid M (2007). Life Cycle Inventories of Energy Systems: Results for Current Systems in Switzerland and other UCTE Countries. ecoinvent report No. 5. Paul Scherrer Institut Villigen, Swiss Centre for Life Cycle Inventories, Dübendorf, $\mathrm{CH}$.

102. Neeft J, te Buck S, GerlaghT, Gagnepain B, Bacovsky D, Ludwiczek N, Lavelle P, Thonier G, Lechón Y, Lago C, Herrera I, Georgakopoulos K, Komioti N, Fehrenbach H, Hennecke A, Parikka M, Kinning L, Wollin P (2012) BioGrace Publishable final report for Grant Agreement IEE/09/736 (http://www.biograce.net/). Accessed: Apr 2013

103. Tobler WR (1970) A computer movie simulating urban growth in the Detroit region. Econ Geogr 46:234-240. doi:10.2307/143141

104. Frischknecht R, Jungbluth N, Althaus H-J, Doka G, Dones R, Heck T, Hellweg S, Hischier R, Nemecek T, Rebitzer G, Spielmann M (2005) The ecoinvent database: overview and methodological framework (7 pp). Int J LCA 10(1):3-9. doi:10.1065/lca2004.10.181.1

105. Bernesson S, Nilsson D, Hansson PA (2004) A limited LCA comparing large- and small-scale production of rape methyl ester (RME) under Swedish conditions. Biomass Bioenergy 26(6):545-559

106. Directive (2009) /28/EC, Directive 2009/28/EC of the European Parliament and of the council of 23 April 2009 on the promotion of the use of energy from renewable sources and amending and subsequently repealing Directives 2001/77/EC and 2003/30/EC. OJL 140/16.

107. Majer S, Oehmichen K (2010) Approaches for optimising the greenhouse gas balance of biodiesel produced from rapeseed.UFOP, project report Available at: http://www.ufop.de/files/9113/3940/7647/Uebersetzung_engl_ Ansaetze_Optimierung_THG_Bilanz_von_RME.pdf. Accessed: Apr 2013.

108. Malça J, Freire F (2011) Life-cycle studies of biodiesel in Europe: a review addressing the variability of results and modeling issues. Renew Sust Energ Rev 15(1):338-351

109. Henseler M, Dechow R (2014) Simulation of regional nitrous oxide emissions from German agricultural mineral soils: a linkage between an agro-economic model and an empirical emission model. Agric Syst 124(0):70-82. doi:10.1016/j.agsy.2013.10.005

110. Heijungs R (1996) Identification of key issues for further investigation in improving the reliability of life-cycle assessments. J Clean Prod 4(3-4):159-166

111. Muller S, Lesage P, Ciroth A, Mutel C, Weidema B, Samson R (2014) The application of the pedigree approach to the distributions foreseen in ecoinvent v3. Int J LCA :1-11. doi:10.1007/s11367-014-0759-5

112. Heijungs R, Suh S, Kleijn R (2005) Numerical approaches to life cycle interpretation - the case of the Ecoinvent' 96 database (10 pp). Int J LCA 10(2):103-112. doi:10.1065/lca2004.06.161

113. Ciroth A, Muller S, Weidema B, Lesage P (2013) Empirically based uncertainty factors for the pedigree matrix in ecoinvent. Int J LCA:1-11 doi: 10.1007/s11367-013-0670-5

114. Maurice B, Frischknecht R, Coelho-Schwirtz V, Hungerbühler K (2000) Uncertainty analysis in life cycle inventory. Application to the production of electricity with French coal power plants. J Clean Prod 8(2):95-108. doi:10.1016/S0959-6526(99)00324-8

115. Heuvelmans G, Muys B, Feyen J (2005) Extending the life cycle methodology to cover impacts of land use systems on the water balance. Int J LCA 10(2):113-119

116. Wicke B, van der Hilst F, Daioglou V, Banse M, Beringer T, Gerssen-Gondelach S, Heijnen S, Karssenberg D, Laborde D, Lippe M, van Meij H, Nassar A, Powell J, Prins AG, Rose SNK, Smeets EMW, Stehfest E, Tyner WE, Verstegen JA, Valin H, van Vuuren DP, Yeh S, Faaij APC (2015) Model collaboration for the improved assessment of biomass supply, demand, and impacts. GCB Bioenergy 7(3):422-437

117. Klassert C, Gawel E, Frank K, Thrän, D (2013) Transregional Land-Use Dynamics of Bioenergy Policies: An Agent-Based Approach. Paper presented at the 10th biennal conference of the European Society for Ecological Economics (ESEE) "Ecological Economics and Institutional Dynamics", June 18th-21st 2013 in Lille, France. Book of abstracts: http://esee2013. sciencesconf.org/conference/esee2013/boa_en.pdf. Accessed: Feb 2015.

118. Gnansounou E, Panichelli L, Dauriat A, Villegas JD (2008) Accounting for indirect land-use changes in GHG balances of biofuels. Review of current approaches, working paper. École Polytechnique Fédéerale de Lausanne. Available at: http://infoscience.epfl.ch/record/121496/files/Accounting_for_ ILUC in biofuels production.pdf Accessed Apr 2014.

119. Jeswani HK, Azapagic A, Schepelmann P, Ritthoff M (2010) Options for broadening and deepening the LCA approaches. J Clean Prod 18(2):120-127. doi:10.1016/j.jclepro.2009.09.023 
120. Tillman AM (2000) Significance of decision-making for LCA methodology. Environ Impact Assess Rev 20(1):113-123. doi:10.1016/S0195-9255(99)00035-9

121. McCormick K, Kautto N (2013) The bioeconomy in Europe: an overview. Sustainability 5(6):2589-2608

122. BMBF, Federal Ministry of Education and Research (2011) National research strategy BioEconomy 2030. http://www.bmbf.de/pub/Natinal_Research Strategy_BioEconomy_2030.pdf. Accessed 5 May 2015.

123. Azapagic A (2010) Assessing Environmental Sustainability: Life Cycle Thinking and Life Cycle Assessment. In: Sustainable Development in Practice. John Wiley \& Sons, Ltd, pp 56-80. doi:10.1002/9780470972847.ch3

124. Dark SJ, Bram D (2007) The modifiable areal unit problem (MAUP) in physical geography. Prog Phys Geogr 31(5):471-479. doi:10.1177/0309133307083294

125. Sutter J (2010) Life cycle inventories of pesticides. Final report ecoinvent v2.2. Swiss Centre for Life Cycle Inventories, St. Gallen, $\mathrm{CH}$

126. Nemecek T, Kägi T, Blaser S (2007) Life cycle inventories of agricultural production systems. Final report ecoinvent v2.0 No.15. Swiss Centre for Life Cycle Inventories, Dübendorf, $\mathrm{CH}$

127. Loiseau E, Roux P, Junqua G, Maurel P, Bellon-Maurel V (2013) Adapting the LCA framework to environmental assessment in land planning. Int J LCA 18(8):1533-1548. doi:10.1007/s11367-013-0588-y

128. Potting J, Hauschild M (2005) Background for spatial differentiation in LCA impact assessment-The EDIP 2003 methodology. Enviornmental Project No. 996, Miløprojekt. Danish Ministry of the Environment

\section{Submit your manuscript to a SpringerOpen ${ }^{\circ}$ journal and benefit from:}

- Convenient online submission

- Rigorous peer review

- Immediate publication on acceptance

- Open access: articles freely available online

High visibility within the field

Retaining the copyright to your article

Submit your next manuscript at $\gg$ springeropen.com 